\title{
Socio-environmental drought response in a mixed urban-agricultural setting: synthesizing biophysical and governance responses in the Platte River Watershed, Nebraska, USA
}

\author{
$\underline{\text { Samuel C. Zipper }}^{1,2}$, Kelly Helm Smith $^{3}$, Betsv Brever ${ }^{4}$, Jiangxiao Qiu $^{5}$, Anthony Kung $^{6,7}$ and Dustin Herrmann $^{8}$
}

\begin{abstract}
Ensuring global food and water security requires a detailed understanding of how coupled socio-environmental systems respond to drought. Using the Platte River Watershed in Nebraska (USA) as an exemplar mixed urban-agricultural watershed, we quantify biophysical response to drought in urban (Lincoln NE) and agricultural systems alongside a qualitative analysis of governance response and adaptive capacity of both sectors. Synthesis of results highlights parallels and discontinuities between urban and agricultural preparations for and response to drought. Whereas drought prompted an increase in well installations and expansion of water-intensive crops, e.g., corn, in the agricultural sector, outdoor water use restrictions rapidly curtailed water withdrawals in the urban sector, where water conservation has gradually decoupled total withdrawals from population growth. Water governance institutions at the municipal, district, and statewide levels showed evidence of learning and adaptive management, facilitated by a shared regional identity around agriculture. We conclude that, rather than exacerbating intersectoral conflict, cities may introduce a high-value and flexible water use that can be rapidly curtailed during drought. The ability to rapidly reduce urban water use and thereby avoid limiting agricultural irrigation during drought enables cities to provide adaptive capacity in mixed urban-agricultural watersheds, particularly where crops are highly reliant on irrigation.
\end{abstract}

Key Words: agricultural water management; drought; irrigation; socio-environmental systems; urban water use; water policy

\section{INTRODUCTION}

Agricultural and urban areas are becoming increasingly interconnected, raising the potential for intersectoral conflict over shared water resources. Population growth is reducing the average amount of cropland per person (Ramankutty et al. 2002) while rapid urbanization is concentrating food production in the vicinity of urban and peri-urban areas (Pearson et al. 2010, Orsini et al. 2013, Thebo et al. 2014). Within this context, managing water resources during drought and preventing intersectoral conflict is a major challenge. Globally, agricultural irrigation is a widespread tool for mitigating negative impacts of drought where available (Ozdogan and Gutman 2008, Wada et al. 2012); however, in many regions, this has led to conflict with both environmental and urban uses of water (McDonald et al. 2011, Grigg 2014, Laukaitis 2014, Wanders and Wada 2015, State of California 2015). Although long-term effects of climate change on drought patterns remain uncertain (Sheffield et al. 2012, Trenberth et al. 2014), historical and projected patterns suggest increasing drought in food producing regions with major population centers, including areas of the U.S. Midwest, central/southern Europe, southeast Asia, and much of Africa (Briffa et al. 2009, Shanahan et al. 2009, Dai 2013). Through this confluence of factors, food and water resources face heightened stress, increasing the likelihood that urban and agricultural users will come into conflict during drought (Kendy et al. 2007, Srinivasan et al. 2013).

Effective water governance mechanisms are key to managing intersectoral conflict (Milly et al. 2008, Wei et al. 2011, Beilin et al. 2012). We refer to governance as the collective efforts of institutions at various scales to establish policy and goals, and to management as a means of implementing goals, including systems of measurement and regulation (Lautze et al. 2011). Irrigators draw from a shared resource, often groundwater. To manage this common pool resource, effective water governance must consider its social and environmental aspects as coupled (Ostrom 1990, 2009, Hornbeck and Keskin 2014). Governance structures that engage with coupled systems tend to demonstrate core characteristics of adaptability, capacity for social learning, sectoral integration, and public participation (Pahl-Wostl 2007, 2009, Huitema et al. 2009, Tan et al. 2012). Pahl-Wostl (2009) describes governance structures that move toward such characteristics as undergoing "triple-loop learning," which is paradigmatic change that extends beyond refining existing actions (single-loop learning) and mere reframing of the problems and goals of water governance (double-loop learning). The need for triple-loop learning is fortified by the recognition that future water availability and future demands are complex and deeply uncertain (Gunderson and Light 2006, Milly et al. 2008, Craig 2010).

Understanding, governing, and managing water resources at the watershed scale, and response to drought in particular, requires a synthetic inquiry incorporating both social and physical science approaches and analysis, which will inform solutions more relevant to real-world complexities (Ostrom 2009, Simelton et al. 2009, Sivapalan et al. 2012, Kiem 2013, Norton 2016, Scanlon et al. 2017, Seidl and Barthel 2017). Specifically, there is a need to understand how existing social and governance systems are equipped to deal with future droughts, and how human activities,

${ }^{1}$ Department of Civil Engineering, University of Victoria, Victoria BC, Canada, ${ }^{2}$ Department of Earth and Planetary Sciences, McGill University, Montreal QC, Canada, ${ }^{3}$ National Drought Mitigation Center, University of Nebraska-Lincoln, Lincoln NE, USA, ${ }^{4}$ Department of Geography and Geographic Information Science, University of Illinois at Urbana-Champaign, Urbana IL, USA, ${ }^{5}$ School of Forest Resources and Conservation, Fort Lauderdale Research and Education Center, University of Florida, Davie FL, USA, International WaterCentre, Brisbane QLD, Australia, ${ }^{7}$ University of Queensland, Brisbane QLD, Australia, ${ }^{8}$ Environmental Studies Program, University of Cincinnati, Cincinnati OH, USA 
Fig. 1. Land use map of the Platte River Watershed (including Loup and Elkhorn subwatersheds) for the year 2011.

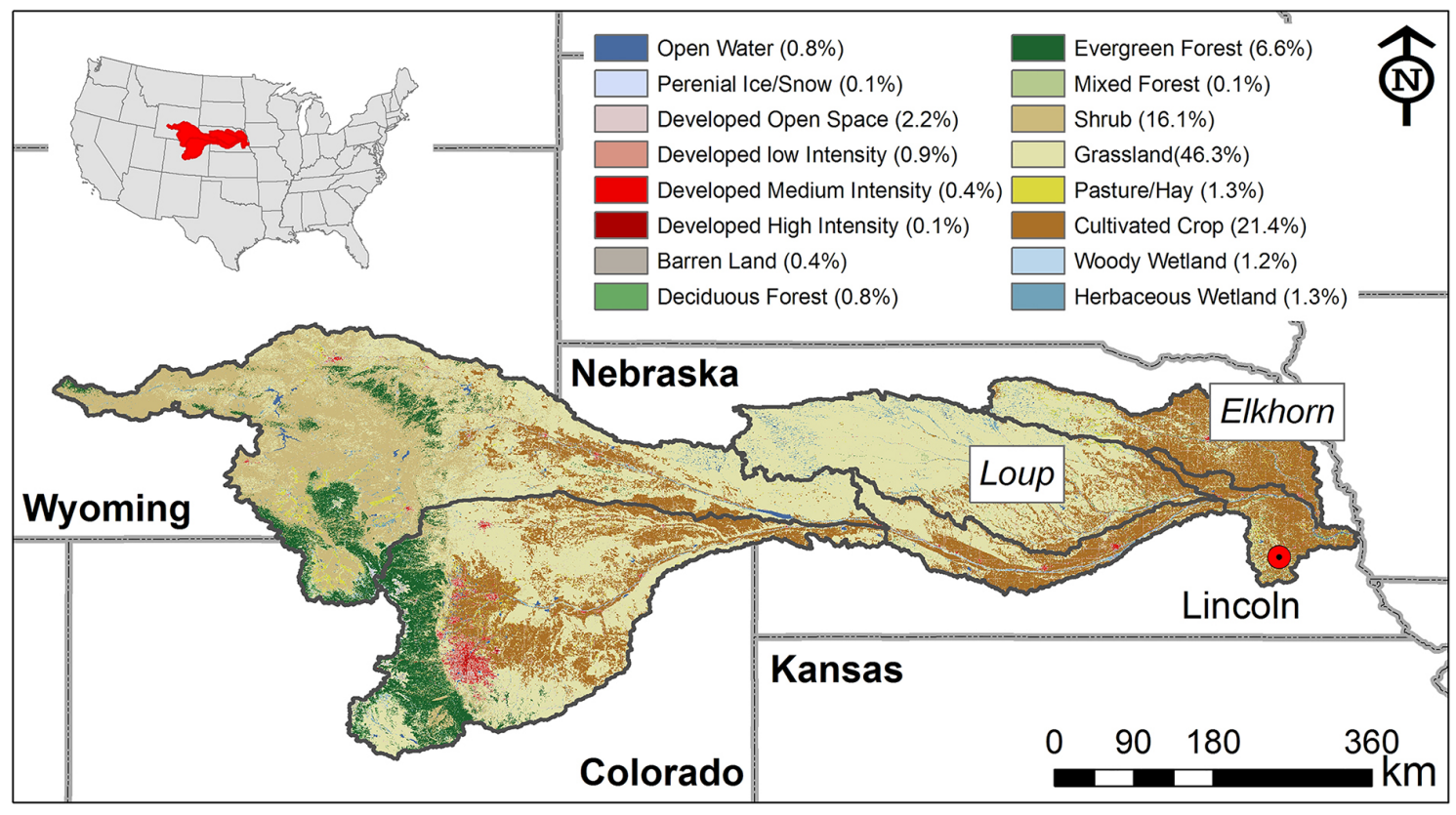

such as abstraction, irrigation, and urbanization, impact the socio-environmental response to drought in human-dominated landscapes (Van Loon et al. 2016a,b). This study takes an interdisciplinary synthesis approach to understanding coupled social and biophysical responses to drought, focusing on potential intersectoral conflict between urban and agricultural water users.

The overarching question guiding our research is, how have socioenvironmental systems responded to past drought, and to what extent have governance institutions demonstrated capability to balance a shared water supply among competing interests? For analysis, we operationalize into three specific questions: (1) How does urban and agricultural water use respond to drought, and what are the implications of those responses for the productivity of urban and agricultural vegetation?; (2) What social and governance mechanisms exist to balance water supply and demand during drought, particularly among competing urban and agricultural users?; (3) Do these systems show evidence of learning? We explore these questions in the Platte River Watershed in the state of Nebraska (USA), which represents an archetypal example of a socio-environmental system based around a shared water resource with a history of drought. We hypothesize that increased irrigation is the primary short-term drought mitigation response in both urban and agricultural settings; that increased irrigation exacerbates intersectoral conflict during drought periods; and that policy responses to past droughts have enhanced the ability of the Platte River governance system to respond to current and future drought conditions.

\section{APPROACH AND METHODOLOGY}

We take a case study approach, whereby broader lessons are generalized from a specific case. Case studies are well suited to exploring complex environmental phenomena like drought, where researchers are not able to manipulate the system variables (Yin 2013). Because generalizing concepts from a single case can be imprecise (Ragin 1992), analysis of multiple data sources are used to triangulate and thus verify the ideas emerging from the case study (Stake 2005). Broadly, drought can be defined as a "temporary lack of water compared to normal conditions" (Van Loon et al. 2016b:3637). In this case study, we use "drought" to refer to meteorological drought (or climate-induced drought), which is drought caused by variability in meteorological conditions from normal (Van Loon et al. 2016b). Recognizing the coupled nature of social and environmental systems in both the propagation and impacts of drought, this paper synthesizes multiple analyses from the physical and social sciences, outlined below, in order to create a multifaceted understanding of both biophysical and governance response to drought.

\section{Study system}

The Platte River Watershed (PRW) and its largest city, Lincoln, bound the case study for this paper. The PRW is a $221,486 \mathrm{~km}^{2}$ watershed extending from headwaters in the Rocky Mountains to its mouth at the confluence with the Missouri River on the Nebraska-Iowa border (Fig. 1). We focus specifically on the portion of the PRW contained within Nebraska $\left(78,471 \mathrm{~km}^{2}\right)$ because it allows us to directly compare governance institutions within a common statewide framework, though we acknowledge that the Platte's flow within the state of Nebraska is impacted by conditions in the headwater states of Wyoming and Colorado. Within the PRW, land use is primarily agricultural, with greater irrigation use in the more arid western part of the state and rainfed agriculture more common in the eastern part of the state (Young et al. 2015). Agricultural production centers on commodity grains, specifically corn, wheat, and soybean (USDA 2014). Irrigation is predominantly fed by groundwater, with much of the 
western part of the PRW overlying the High Plains (Ogallala) Aquifer system. Lincoln NE is a city of 280,000 residents (U.S. Census 2017) situated in the Salt Creek subwatershed, a tributary in the southeastern part of the PRW near the confluence with the Missouri River. Lincoln draws its water from a wellfield near Ashland NE, on the Platte River, below the confluence of the Loup River (Fig. 1).

The PRW has broad global relevance as a case study of the interplay between urban and agricultural water use in a droughtprone landscape. Worldwide, half of all urban residents are found in midsized cities such as Lincoln (population 100,000-500,000), compared to $<10 \%$ in mega-cities (Cohen 2006). As an urban area surrounded by agriculture, it is also representative of a globally prevalent pattern of land use: worldwide, an estimated $60 \%$ of irrigated agriculture and $35 \%$ of rainfed agriculture is within $20 \mathrm{~km}$ of an urban area (Thebo et al. 2014). Because of the availability of groundwater, the PRW is among the most densely irrigated areas worldwide (Doell and Siebert 1999) and therefore represents a study site where we expect drought to strongly impact water resources, which can inform future water resource development across the globe. Importantly, the PRW has experienced multiple droughts in recent history that provoked a variety of biophysical and institutional responses, including mandatory water use restrictions in the city of Lincoln in 2002 and 2012, and voluntary conservation from 2003-2009 (further details in Appendix 1).

Furthermore, the State of Nebraska has implemented a distinctive system of groundwater governance that observers have described as a broad-scale experiment in local control (Bleed and Hoffman Babbitt 2015). Like most states in the western USA, Nebraska has separate administration of ground and surface water resources. Surface water is administered by the state government under the doctrine of prior appropriation, and groundwater by natural resource districts under a system of modified correlative rights (Hoffman and Zellmer 2013). In 1975, Nebraska delegated authority for groundwater management to 23 natural resource districts (NRDs) that have boundaries approximately corresponding to watersheds, and that have locally elected boards. The districts' authority goes beyond water, incorporating conservation projects and other natural resource management. In 2004, Legislative Bill (L.B.) 962 mandated that surface and groundwater be managed conjunctively, and designated some western basins within the state as fully or overappropriated. The law defines a fully appropriated basin as one in which current uses of hydrologically connected water will result in inadequate supplies for current beneficial uses of surface or groundwater (Bleed and Hoffman Babbitt 2015). NRDs managing fully and overappropriated basins are required to work with the state's Department of Natural Resources to create and implement integrated water management plans (IMPs), including "Clear goals and objectives with a purpose of sustaining a balance between water uses and water supplies so that the economic viability, social and environmental health, safety, and welfare of the river basin, sub-basin, or reach can be achieved and maintained for both the near term and the long term" (Neb. Rev. Stat., 46-715). The history and structure of water governance in Nebraska is discussed in detail in Appendix 2.

Previous work on agricultural drought sensitivity in Nebraska highlighted the importance of irrigation (Wilhelmi and Wilhite
2002, Hornbeck and Keskin 2014). In the PRW and much of Nebraska, groundwater levels have dropped substantially from predevelopment conditions in response to irrigation, though levels have stabilized since 1981 in many locations (Burbach and Joeckel 2006, Young et al. 2015). Although no previous studies have analyzed the response of urban water use to drought in Lincoln, a recent study has found that water use in Lincoln is correlated with urban population density and responds to precipitation ( $\mathrm{Li} 2013$ ); work elsewhere has found strong evidence for urban water use responding to both drought and governance actions such as water restrictions (Kenney et al. 2004, 2008, Mini et al. 2015). However, little is documented in the scholarly literature about interactions between agricultural and urban users, and how those relationships may change during drought.

\section{Biophysical analysis}

\section{Drought quantification}

Two distinct meteorological data sources were used to quantify historical meteorological drought. For the City of Lincoln, we obtained daily precipitation and maximum/minimum temperature from the Global Historical Climatology Network-Daily (GHCND) station at the Lincoln Airport (1972-2014; station USW00014939). Monthly potential ET was calculated using a modified form of the Hargreaves (1994) equation (Droogers and Allen 2002). In addition to temperature and precipitation, we used the Standardized Precipitation Evapotranspiration Index (SPEI; Vicente-Serrano et al. 2009) as a metric of drought severity. The SPEI provides two key advantages over other drought indices, such as the Palmer Drought Severity Index, for our study application. First, the SPEI represents drought severity as a standardized variable along a continuous spectrum from dry to wet conditions which allows for direct comparison across locations (Alley 1984, Chen et al. 2013, Vicente-Serrano et al. 2015). This is critical for our study because of the longitudinal precipitation gradient present in our study area. Second, the SPEI can be used across a variety of timescales to analyze droughts of different durations, because different biophysical systems may respond to drought at different timescales (Vicente-Serrano et al. 2013, Potopová et al. 2015, Zipper et al. 2016). We calculated SPEI at $1-12,18$, and 24 month time scales using the $\mathrm{R}$ package "SPEI" (Begueria and Vicente-Serrano 2013).

For county-level analysis of yield response to drought conditions, we used a gridded $\left(0.08333^{\circ}\right.$ resolution) daily meteorological dataset consisting of precipitation, minimum/maximum temperature, average relative humidity, wind speed, and incoming solar radiation for the period 1948-2007. This dataset was generated by synthesizing meteorological and gridded datasets from multiple sources and scales and is described in Motew and Kucharik (2013). At each point within our area of interest, we calculated daily Penman-Monteith reference ET (Allen et al. 1998 ) and the monthly water deficit. Monthly water deficits were used to calculate gridded SPEI at $1-12,18$, and 24 month timescales and aggregated to county averages for comparison with crop yield data.

\section{Agricultural data}

To analyze the agricultural response to meteorological drought, we obtained annual yield and area harvested data for all Nebraska counties completely or partially contained within the boundaries of the PRW from the U.S. Department of Agriculture National Agricultural Statistics Service (USDA NASS; http://www.nass. 
usda.gov/Quick Stats/). Specifically, we obtained irrigated and nonirrigated corn and wheat yield from 1953 to 2014 (corn) and 1956 to 2007 (wheat). These crops are the predominant waterintensive crop for the region (corn) and a widely used lower wateruse alternative (wheat). We used irrigated and nonirrigated corn and wheat area harvested for the same counties and timescales to study agricultural land use and management decisions in response to drought. Combined, these two crops represent $55.9 \%$ of Nebraska's total field crop planted area $\left(7.6 \times 10^{6} \mathrm{ha}\right)$ for the year 2010 . Corn is $47.6 \%$ of total planted area $\left(3.7 \times 10^{6} \mathrm{ha}\right)$, of which $59.2 \%$ is irrigated; while wheat is $8.3 \%$ of total planted area $(6.5$ $\mathrm{x} 10^{5} \mathrm{ha}$ ), of which $8.9 \%$ is irrigated. The other dominant crop in the region is soybean $\left(2.1 \times 10^{6} \mathrm{ha} ; 26.8 \%\right.$ of planted area), often in corn-soybean rotations.

Reported yield data were linearly detrended for each county to account for the effects of hybrid and technological improvements (Wu et al. 2004, Mavromatis 2007, Sun et al. 2012, Potopová et al. 2015). Annual yield residuals were compared to the countyaverage July 1-month SPEI for each year because drought during the critical pollination period have been shown to exert the largest impact on yield both in field studies (Hiler and Clark 1971, Çakir 2004, Boyer and Westgate 2004, Zipper and Loheide 2014, Zipper et al. 2015) and nationwide (Zipper et al. 2016). We calculated the annual ratio of corn planted area to wheat planted area as an indicator of farmer shifts from more water-intensive (corn) to low-water-use (wheat) crops, which we hypothesized would occur in response to drought conditions.

As a proxy for farmer investment in infrastructure in response to drought, we downloaded a georeferenced record of all groundwater wells registered within the state of Nebraska from the Nebraska Department of Natural Resources (http://www.dnr. ne.gov/gwr) and also calculated the ratio of irrigated to nonirrigated area harvested for both corn and wheat. Other proxies for irrigation extent, such as estimates of county-level water use, are not available as time-series data, or have coarser temporal resolution or insufficient temporal extents; the U.S. Geological Survey's county-level water use reports (http://water. usgs.gov/watuse/), for example, are only available since 1985 and at 5-year resolution. However, these data are useful to provide context as to the relative importance of different water users; we obtained 2010 estimated water use data by sector to estimate the contribution to total water use of different sectors, e.g., irrigation, domestic, industrial, etc.

\section{Urban data}

We calculated monthly per-capita water use (liters per capita per day, or LCPD) in the City of Lincoln from 1995 to 2014 using total monthly water withdrawals by annual service area population estimates provided by the City of Lincoln Water System. We then isolated the seasonal component of LCPD by subtracting mean winter LCPD (December through February) from total LCPD. Previous studies have shown that urban water use incorporates both climate-sensitive and climate-insensitive processes (Maidment and Miaou 1986, Gato et al. 2007). Winter use is a proxy for indoor, climate-insensitive water use that occurs year-round. Seasonal use represents the climate-sensitive component of water use associated with irrigation and other outdoor water uses that tend to reach their peak in summer (Breyer et al. 2012).
We used remotely sensed data on urban greenness as a metric for urban vegetation response to drought. To assess urban greenness, we obtained 16-day gridded data of the Enhanced Vegetation Index (EVI; 250 meter pixels) and pixel reliability data over the interval 2000-2014 from the U.S. Geological Survey Moderate Resolution Imaging Spectroradiometer (MODIS) reprojection tool web interface (MRTWeb). We then derived a citywide time series of urban greenness by clipping each image to the City of Lincoln boundary and calculating a mean EVI value. To pair EVI with monthly urban water use data, the 16-day EVI time series was linearly interpolated to daily values and reaggregated to monthly mean values. We plotted monthly seasonal LCPD against EVI to determine whether their relationship had shifted over the course of the 2002 and 2012 droughts.

To assess how the urban system responded to drought, we fit two generalized least square regression models to explain drought response variables, seasonal LCPD and EVI. Each model was specified as a function of monthly mean maximum air temperature (TMAX, ${ }^{\circ} \mathrm{C}$ ), SPEI (two month lag), and an extreme heat variable $\left({ }^{\circ} \mathrm{C}\right)$ indicating the number of degrees above $30^{\circ} \mathrm{C}$ in that month. Analysis focused on the months of April through October, a period in which urban water use was responsive to climate variability. All variables were standardized (divided by their standard errors) and mean-centered on zero. Each model withheld data in the time periods when water restrictions were imposed. Using these models, we generated predicted values for drought response variables, along with prediction intervals, during the period when water restrictions were imposed. We then compared predicted and observed values of seasonal LCPD and EVI. Finally, loess regression was used to visualize the relationship between EVI and LCPD as well as the relationship between population and total water withdrawals over time.

\section{Governance analysis}

To document the experience of and response to drought in the study area, we categorized 269 media stories originating in Nebraska on drought in the state and in the PRW, using a recursive approach consistent with grounded theory (Creswell 2012). The stories were collected from 2009 to mid-2015 in the National Drought Mitigation Center's drought impact reporter (DIR) database using a daily automated search of a purposively sampled list of media sources.

Our broad-scale analysis of news stories was both emic, looking for what triggered a news story, such as lack of water for crops, urban water use restrictions, or fire; and etic, seeking information on drought responses that were relevant for our focus on coupled urban-agricultural systems. This established a connection between water-related policy initiatives and drought, and provided an initial historic record. We chose this existing collection of media stories about drought because it had the advantage of being a precurated, representative collation developed by experts; however, possible disadvantages of using this source are that it is not as tailored to our study objectives or as systematic as independent data-gathering would have been.

To supplement and verify the DIR database, we incorporated other publicly available documents to develop a more complete historic narrative of drought-related policy initiatives, and to situate drought responses within the larger context of water policy. These additional sources included media stories not in the 
Fig. 2. (a, b) Slope of the Yield-SPEI (Standardized Precipitation Evapotranspiration Index) relationship for each county within the Platte River Watershed. Scale bar in (a) applies to both (a) and (b). Because a negative SPEI corresponds to more severe drought, a positive slope indicates yield losses in response to drought. ** p < $0.05(* \mathrm{p}<0.10)$. (c, d) Irrigated and nonirrigated slope and adjusted $\mathrm{R}^{2}$ for all counties with $\mathrm{p}<0.10$.
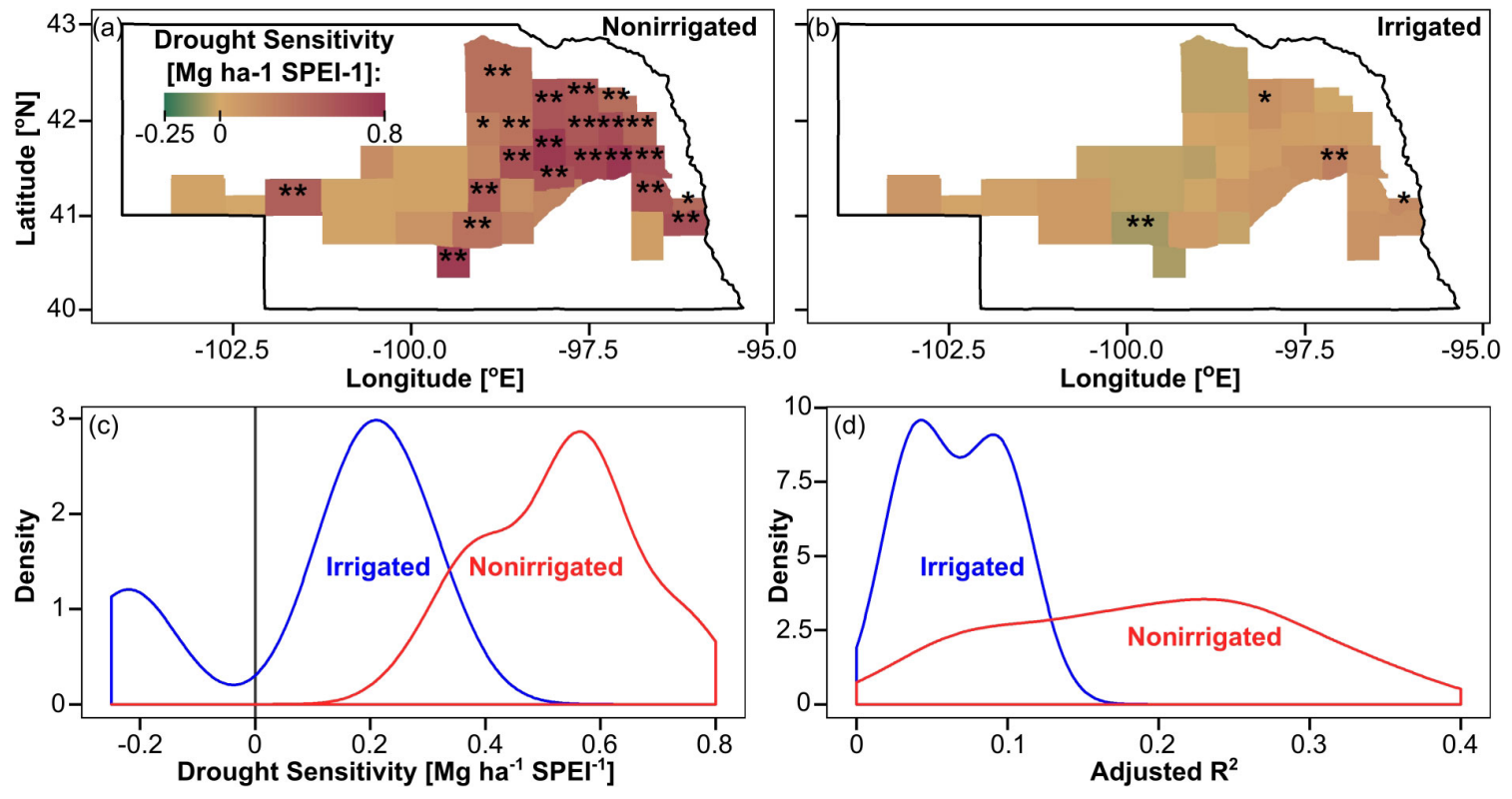

collection from the DIR. These stories were not in the DIR because they did not use the word "drought," but they contained essential historic information, such as the resolution of litigation and other issues. One member of the research team did the categorizing, sifting, and construction of narrative.

The research team then interpreted this narrative through an adaptive capacity lens; namely, whether the governance system learned from drought to become better able to adapt to uncertainty. As an assessment framework, we adopted the criteria of Pahl-Wostl (2007, 2009) and Pahl-Wostl et al. (2010), which include the following:

- Management paradigm taking into account system complexity and learning from experience, rather than emphasizing top-down control;

- Governance style, polycentric rather than centralized, involving stakeholders in participatory processes, integrating bureaucratic hierarchies, markets, and networks;

- Sectoral integration, identifying emerging problems and solutions holistically rather than one sector at a time;

- Scale of analysis and operation, addressing transboundary issues through multiple scales of analysis and management, rather than a single river basin or sub-basin;

- Information management, with data openly shared;

- Infrastructure less reliant on large-scale projects and more emphasis on scale-appropriate projects;

- Financial investment and incentives spread broadly, not just in large-scale infrastructure.
This approach complements a previous analysis of water governance systems by Hoffman and Zellmer (2013), which evaluates whether Nebraska's water management institutions have the flexibility to implement adaptive, integrated management, following Doremus (2001), as well as a recent study focusing on the effectiveness of Nebraska's NRDs for common pool governance by Hoffman Babbitt et al. (2015). These previous evaluations are described in detail in Appendix 2. Pahl-Wostl's criteria go beyond whether a governance system can learn from experience and implement incremental change in its management procedures to consider whether systems can fundamentally change themselves, and provides a means for evaluating institutional mechanisms for balancing different water uses.

\section{RESULTS AND DISCUSSION}

\section{Agricultural response to drought}

In agricultural systems, irrigation is an effective tool for eliminating the negative impacts of drought on productivity. We found that yield of nonirrigated corn decreased significantly in response to drought across the PRW (Fig. 2a), particularly in eastern Nebraska where rainfed agriculture is more common. In contrast, irrigated corn yield was not affected by drought over most of the study area, with a statistically significant relationship in only four counties (Fig. 2b). Yield losses were $\sim 2 \mathrm{x}$ more severe for a given drought severity in nonirrigated corn compared with irrigated corn, and drought severity explained a higher proportion of interannual yield variability in nonirrigated corn (Fig. 2c-d). These multiple lines of evidence indicate that, where available, irrigation was being effectively used as a tool for creating agricultural drought resistance by providing an ancillary supply of water when precipitation was insufficient and decoupling corn yield from drought severity. 
Data reflecting agricultural management practices revealed a shift toward an irrigation-reliant system of drought resistance, likely in response to its observed effectiveness in decoupling yield from drought. Figure $3 \mathrm{a}$ shows the number of irrigation wells completed annually in each NRD. Two important patterns are visible here. First, there was a PRW-wide expansion of irrigation which exhibited a marked uptick in the 1990s and 2000s. While certain NRDs, such as the Central Platte, have had high rates of well installation throughout their history, other NRDs, e.g., Upper Loup or Lower Platte South, have only recently begun to adopt large-scale irrigation as a drought mitigation practice. Second, a strong, reactive management response to drought conditions was nested within the larger trend of overall increasing irrigation. Spikes in well installations accompanied or immediately followed years with severe droughts, often factors of $\geq 2$ higher than background levels.

Fig. 3. (a) Number of completed wells per year in each of the three study watersheds. (b) Proportion of total harvested acreage that is irrigated for both corn and wheat over time. (c) Ratio of corn to wheat planted on nonirrigated land over time. (d) Annual averaged corn price from the University of Illinois FarmDoc program (http://www.farmdoc.illinois.edu/). In each plot, dashed lines mark droughts in 1954, 1976, 1988, 2002, 2006, and 2012.

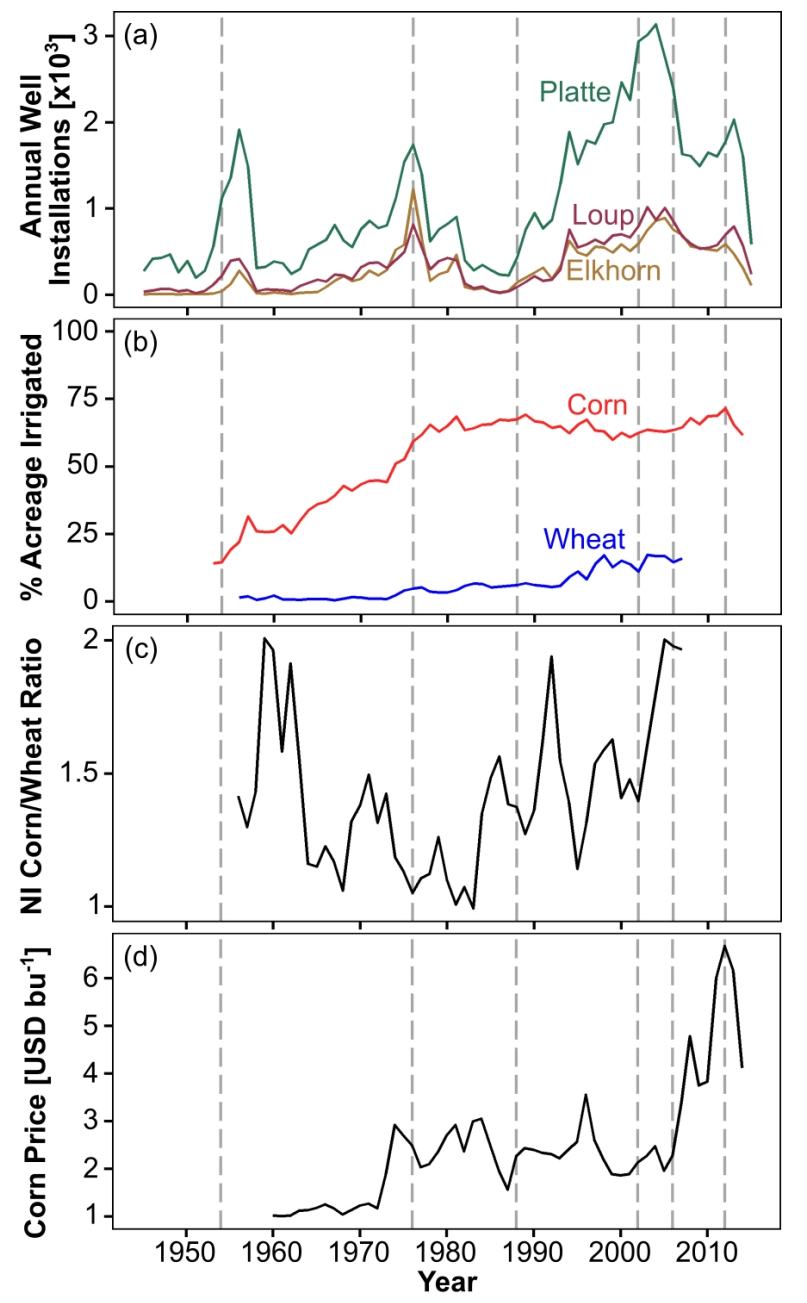

Similarly, agricultural land use practices indicated a shift toward irrigation-reliant drought resistance. Figure $3 \mathrm{~b}$ shows the proportion of total corn and wheat planted that was irrigated. In the 1960s and 1970s, irrigated corn became standard practice, and a relatively consistent $60-75 \%$ of total corn has been irrigated since 1975; while the proportion of irrigated corn has plateaued, net irrigated acreage is still increasing steadily. Wheat showed a more recent shift toward irrigation reliance, as the irrigated wheat area experienced a rapid increase in the early 1990s. Within nonirrigated land, a long-term increase in the ratio of corn to wheat planted area was evident since the mid-1970s (Fig. 3c), concomitant with the increase in irrigation observed (Fig. 3b). This indicates a shift away from dryland, low water use crops (wheat) toward higher water use but more economically valuable crops (corn). We attribute this trend primarily to a similar longterm trend in increasing corn prices (Fig. 3d), potentially driven in part by federal biofuel mandates, though the contribution of ethanol policy to corn price variability is highly uncertain (McPhail and Babcock 2012, Condon et al. 2015). Years during and immediately following drought were often characterized by a slight decrease in the corn/wheat ratio. This indicates temporary management responses to reduced water availability. However, after a drought, corn/wheat ratio eventually rebounded to predrought levels or greater.

Taken in aggregate, these results point to an "all eggs in one basket" approach: irrigation as the sole means of agricultural drought resistance in the PRW. This approach is self-reinforcing because of increased infrastructural investment in irrigation (Hornbeck and Keskin 2014). Our observations indicate that irrigation has dramatically decreased the sensitivity of corn yield in the PRW to drought conditions, agreeing with statewide patterns (Zipper et al. 2016). The rapid shift away from dryland agriculture toward irrigated systems indicates agriculture is becoming more resistant to drought in the short term. However, this drought resistance relies on irrigation alone, and other steps that may mitigate negative drought impacts and reduce the impacts of agriculture on local water resources, e.g., mixed use of dryland crops, are not being taken.

At a state scale, observations indicate that groundwater abstraction is currently mostly in equilibrium with recharge rates over multiyear timescales (Young et al. 2015). However, the expansion of irrigation we observe in Figure 3 may decrease the ability of the water table to rebound during wet years. Because of the strong groundwater response to drought in agricultural areas, future climates with increased frequency, severity, and/or duration of drought in conjunction with the expansion of irrigation may lead to water table drawdown past sustainable limits, particularly in areas with rapid expansion of irrigation such as the Central Platte NRD, if the wetter periods following drought are less frequent or shorter in duration (Burbach and Joeckel 2006).

\section{Urban water use}

Regression results in Table 1 indicate urban water use (LCPD) and urban greenness (EVI) exhibited positive, tightly coupled relationships with air temperature. More severe drought (negative values for SPEI) and high temperatures (heat index) increase water use and reduce greenness. Predicted values during the droughts of 2002 and 2012 indicated that water restrictions did result in reduced LCPD and lower EVI values. On average, outdoor 
Table 1. Standardized coefficients from generalized least square models of seasonal water use and urban greenness as a function of climate. $p<0.001$ for all variables.

\begin{tabular}{llccc}
\hline \hline $\begin{array}{l}\text { Dependent } \\
\text { variable }\end{array}$ & $\begin{array}{l}\text { Explanatory } \\
\text { variable }\end{array}$ & $\begin{array}{l}\text { Estimated } \\
\text { coefficient }\end{array}$ & $\begin{array}{c}\text { Standard } \\
\text { error }\end{array}$ & T-statistic \\
\hline $\begin{array}{l}\text { Seasonal } \\
\text { LCPD }\end{array}$ & TMAX & 1.154 & 0.098 & 11.769 \\
& SPEI, 2 month & -0.224 & 0.043 & -5.239 \\
& lag & & & \\
& Heat index & 0.274 & 0.048 & 5.689 \\
EVI & TMAX & 0.868 & 0.060 & 14.527 \\
& SPEI, 2 month & 0.143 & 0.027 & 5.376 \\
& lag & & & \\
& Heat index & -0.108 & 0.028 & -3.806 \\
\hline
\end{tabular}

LCPD, liters per capita per day; EVI, Enhanced Vegetation Index; TMAX, monthly mean maximum air temperature; SPEI, Standardized Precipitation Evapotranspiration Index.

watering restrictions reduced seasonal per-capita water use 57.5 LCPD and reduced EVI 0.04 units relative to predicted values.

Rapid decreases in EVI were evident in months when water use restrictions were implemented (Fig. 4b). This indicates that Lincoln vegetation was sensitive to drought under curtailed irrigation. Interestingly, reduced urban greenness was not sustained over subsequent years. The quick rebound suggests that existing vegetation structure survived through the water restrictions. The maintenance of greenness over the study period is also interesting because water use was declining throughout the study period (Fig. 4a). Generally, loess regression showed EVI increased nonlinearly with LCPD; however, Figure 4a shows a given EVI level in 2014 was attained with a lower LCPD than in 2000 , indicating that reductions in urban greenness are not a necessary byproduct of reduced domestic water use.

Over longer time periods, ongoing water conservation has resulted in a decoupling of population growth from municipal water withdrawals. Contrary to an ongoing discourse around urbanization as a key driver of regional water stress (Vano et al. 2010), urban water withdrawals for Lincoln have decreased over time even as the population has increased. This is consistent with water use trends across U.S. cities (Coomes et al. 2010). Water withdrawals in Lincoln during the months of April-October declined from 6370 million liters per day in 2000 to 5077 in 2014, despite a $19 \%$ increase in Lincoln's population from 225,600 to 269,500 people. Thus, per capita water conservation is even more pronounced: in 2014, the average Lincoln resident used 367 LCPD in winter and 615 LCPD in summer, a decrease of 106 LCPD (winter) and 310 LCPD (summer) from 2000 levels (Fig. 4c).

At the PRW scale, the City of Lincoln's current water use is relatively small compared to agricultural irrigation, though locally it can be quite important. Over the entire PRW in 2010, Lincoln's water use was $1.0 \%$ of total irrigation withdrawals, and total domestic, public supply, and industrial use over the watershed was $6.4 \%$ of total irrigation withdrawals. Locally, however, there is significant variability in the proportion of total human water use going to irrigation. In 6 of the 46 counties within the PRW, agricultural irrigation withdrawals constituted $<50 \%$ of total water use. Four of these counties (Cass, Lancaster, Sarpy, and Saunders) are the most urbanized in the state representing greater Omaha and Lincoln metropolitan areas. The other two are sparsely populated with little agriculture.

Fig. 4. (a) Enhanced Vegetation Index (EVI) as a function of per-capita daily water use. (b) EVI as a function of monthly maximum temperature. Summer values during mandatory water restrictions are highlighted in orange (2002) and brown (2012) and fall significantly below a loess curve fit to data during periods of voluntary or no restrictions. (c) Winter urban water use data demonstrates ongoing passive conservation, at a rate of $\sim 2 \%$ annually.
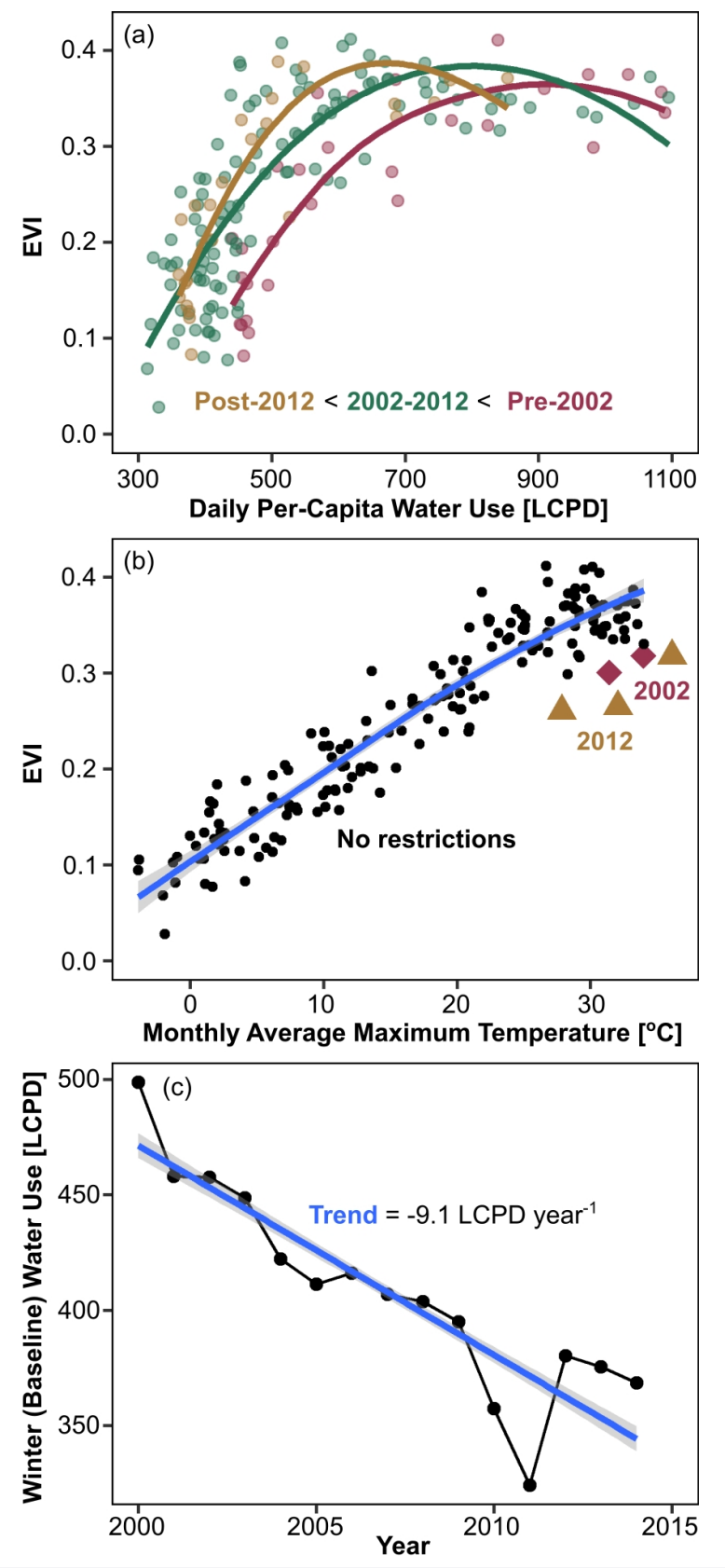
Fig. 5. Figure outlining conceptual overview of governance (yellow color), agriculture (green), and urban (gray) analysis, highlighting areas of synthesis (blue).

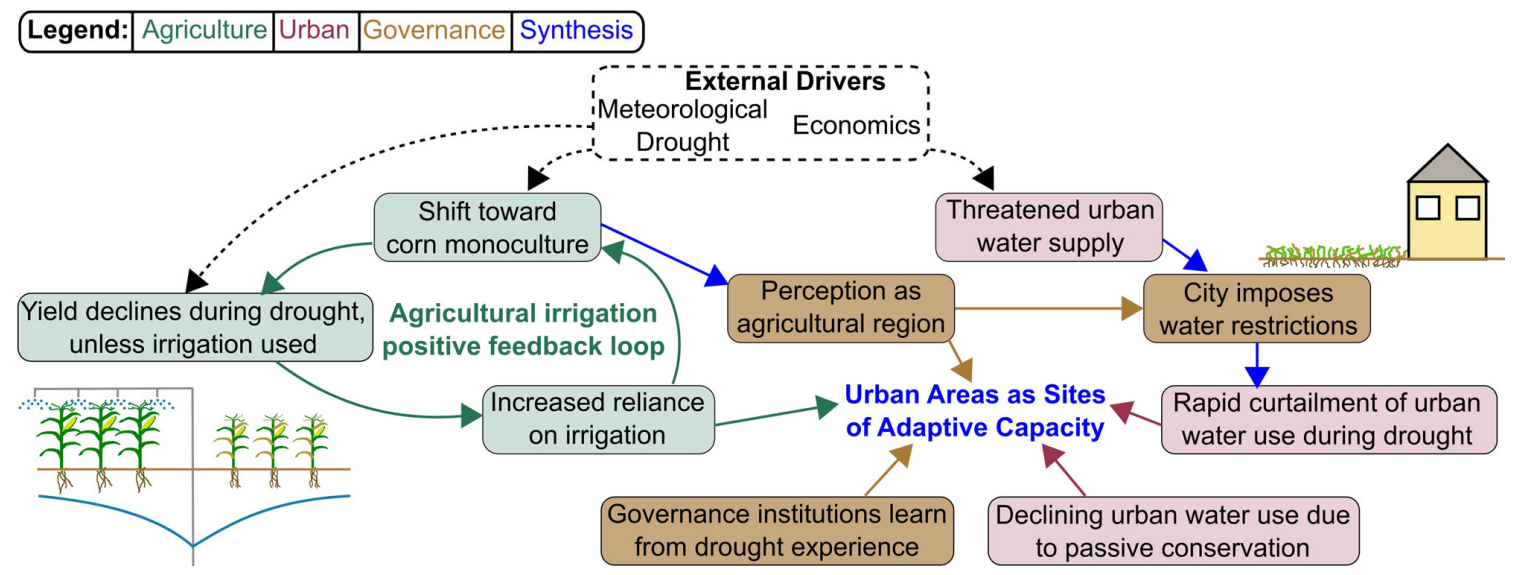

Our results suggest that, rather than exacerbating watershed-scale vulnerability to drought, urban water consumption can represent a source of flexibility within socio-environmental systems (Fig. 5). During drought, outdoor irrigation can be rapidly curtailed without long-term effects on city-scale urban vegetation. The willingness of urban users to reduce water consumption was demonstrated in practice in 2012, as discussed in the following section. Over longer time periods, ongoing trends in passive conservation have offset the effects of population growth, such that a growing city has a smaller hydrological impact. Furthermore, there appears to be capacity for further reductions in LCPD to accommodate potential increases in population or in agricultural use, as water use remains 100-200 LCPD higher in Lincoln than, for example, European cities (Saurí 2013). Collectively, the short- and long-term water conservation measures can limit resource conflict between urban and agricultural water users in the same watershed, particularly in watersheds like the PRW where agricultural reliance on irrigation is increasing.

Social and governmental experiences and responses to drought The findings from our analysis of news stories provided a means to systematically sift reports to identify emergent, relevant initiatives and issues regarding experience of and response to drought in the PRW. Two almost mutually exclusive categories emerged, dealing with "monitoring," i.e., how bad is the drought, or "response," what is being done about it? Some stories dealing with specific impacts did not include either of these elements. Of the 95 stories that incorporated monitoring and 52 that mentioned response, only two overlapped. Stories that mentioned the "Climate Assessment and Response Committee" without a primary focus on it were not coded as "response."

Response stories were categorized based on whether they were routine responses to conditions, or whether they were intended to have effects in the future, with 28 stories focusing on short-term responses, and 24 on long-term measures. Six of the response stories dealt with federal responses such as speculation about when a Farm Bill would be passed; because these mentions were general and sometimes symbolic, and federal response was beyond the scope of this effort, these stories helped provide context but the federal responses mentioned were not considered in our adaptive capacity rubric. Examples of short-term measures mentioned are emergency road-side haying, requests for water conservation, and closing cracked bike trails. Long-term measures included both technical responses, i.e., drilling more wells, either municipal or agricultural, and policy responses, such as new initiatives to regulate groundwater. Of the response stories, 20 talked about agriculture, including three that also mentioned urban water supply and four that mentioned surface watergroundwater; 10 dealt with surface water and groundwater, which has been a prominent topic in Nebraska water policy; 14 addressed urban supply issues, nearly all related to Lincoln; six talked about rural domestic water supply; four dealt with fire (positioning more resources in western Nebraska); three were about trees; and two dealt with wildlife (fish salvage).

The full narrative that we developed on the PRW governance system's collective response to drought forms Appendix 3. The narrative focuses on water for agriculture, governance, and management of hydrologically connected surface water and groundwater, urban water supply, and rural domestic water supply. Key drought impacts reported in media were widespread curtailment of surface water irrigation to protect in-stream flows for fish; rural domestic and municipal wells in agricultural areas running dry; and the City of Lincoln imposing mandatory water restrictions. Key responses reported in media were record numbers of irrigation wells being drilled; the City of Lincoln drilling a new well and beginning more drought-oriented planning; natural resources districts implementing restrictions on groundwater pumping; natural resources districts undertaking basin-level planning; and at least one natural resources district undertaking more drought-related planning on its own.

The importance of protecting agriculture, the backbone of the state's economy, came up several times, notably when the mayor of Lincoln implored residents to conserve water to help protect upstream agricultural production during the 2012 drought. Despite the negative impacts of the drought, support for agricultural irrigation within the watershed remained strong. When irrigators objected to proposed irrigation restrictions at a public meeting, local water suppliers expressed support for 
Table 2. Analysis of adaptive capacity in the Platte River Watershed (PRW) under the Pahl-Wostl (2007, 2009) and Pahl-Wostl et al. (2010) framework.

\begin{tabular}{|c|c|}
\hline Criteria & Evaluation in the Platte River Watershed \\
\hline $\begin{array}{l}\text { (1) Management paradigm taking into account } \\
\text { system complexity and learning from experience, } \\
\text { rather than emphasizing top-down control; and } \\
\text { (2) governance style, polycentric rather than } \\
\text { centralized, involving stakeholders in } \\
\text { participatory processes, integrating bureaucratic } \\
\text { hierarchies, markets and networks. }\end{array}$ & $\begin{array}{l}\text { Short-term responses tended to be more urgent and top-down, within pre-existing hierarchies, } \\
\text { whereas long-term planning incorporated more stakeholders and networked interests. During } \\
\text { drought, the Lincoln Water System imposed mandatory watering restrictions, and irrigation } \\
\text { curtailments by the state's Department of Natural Resources were an exercise of its regulatory } \\
\text { function. natural resource districts' (NRDs) slowing development of irrigation in eastern Nebraska } \\
\text { to protect domestic and municipal supplies was also an exercise of regulatory authority. This } \\
\text { suggests that being in crisis mode, when people are facing imminent trade-offs such as agricultural } \\
\text { production vs. urban demand, triggers more top-down reactions. However, these reactions proceeded } \\
\text { according to previously understood and developed rules. Authorities were executing their assigned } \\
\text { functions. The planning and evaluation that occur in the aftermath of drought are opportunities for } \\
\text { learning, and typically involve a broader network of agencies and interests. }\end{array}$ \\
\hline
\end{tabular}

(3) Sectoral integration, identifying emerging problems and solutions holistically rather than one sector at a time.

(4) Scale of analysis and operation, addressing transboundary issues through multiple scales of analysis and management, rather than a single river basin or sub-basin.

(5) Information management, with data openly shared.

(6) Infrastructure: preferably less reliance on large-scale projects, and more emphasis on scaleappropriate projects.

(7) Financial investment and incentives spread broadly, not just in large-scale infrastructure.
Planning before problems actually arise is an opportunity to think holistically about resource use, rather than responding to a shortfall in one particular sector or a conflict between water users. The explorations called for in the Lower Platte South Natural Resources District's (LPSNRD) voluntary integrated water management plans (IMPs) and the seven-basin planning effort to protect dry-year water uses while allowing development of water resources in the Elkhorn and Loup basins are opportunities to plan holistically. However, the reliance on irrigation, and the primacy of agriculture in the public discourse, may later require deeper transformations that are largely undebated as yet.

The seven-NRD basin-level planning initiative represents a networked, multiscale, multiactor planning processes, with urban needs explicitly recognized alongside agricultural needs, all steps toward the kind of dispersed authority that is associated with enhanced adaptive capacity. The requirement that the state and NRDs work together on IMPs and on annual evaluations of water supplies provides accountability across scales.

Increasing collection, use and sharing of scientific data is part of the overall direction of water governance in Nebraska, although not all NRDs have opted to collect data on how much water irrigators are pumping. The 2004 legislation requires fully and overallocated NRDs to work with the state to reassess water supplies each year, a process based on data and modeling, and clearly incorporating an opportunity to learn from experience. Changes related to information management in response to recent drought were not apparent from media analysis.

Lincoln's new well and anticipated new well field appear to be scale-appropriate. Farmers' new - irrigation wells are scaled to their individual needs, although the investment may discourage alternative uses of the land. No significant plans were announced within Nebraska for large-scale infrastructure projects. LPSNRD's voluntary IMP anticipates exploring new options such as water reuse and regional systems, scale-appropriate means of expanding available supplies.

LPSNRD's voluntary IMP anticipates exploring new options such as water banking that expand water supplies by changing legal definitions and institutions, although some infrastructure investment may be needed. irrigators and pointed to drought as a common enemy: "Greg Bouc, the water plant operator for Valparaiso, applauded the NRD for trying to make the changes, saying that in the past 30 years he has never seen the water table drop at the rate it has in the past year. 'The biggest enemy in this room is not the irrigators or municipalities, it's the drought,' Bouc said" (Laukaitis 2014). The City of Lincoln also sacrificed to help sustain agricultural users. Rather than exercising its water rights during low flows in the Platte River near its Ashland well field, Lincoln implemented mandatory water conservation. The mayor was quoted as saying, "We realize that agriculture is the economic backbone of this city and region, and this is a critical time for our ag producers" (Hicks 2012).

\section{Evaluating the effects of drought responses on adaptive capacity and system learning}

Using this record of system response to drought, we assessed whether the coupled socio- environmental system in the PRW is increasing its capacity to respond to future droughts based on Pahl-Wostl's characteristics of systems with greater adaptive capacity (Pahl-Wostl 2007, 2009, Pahl-Wostl et al. 2010). Institutional response to drought as described above is evaluated under this framework in Table 2. Overall, we find that Nebraska's L.B. 962 (which was passed in 2004 and mandated conjunctive management of groundwater and surface water) represented a significant evolution of water management in the PRW, and state of Nebraska as a whole. It closed a key gap in regulation that had previously allowed irrigators' relatively unchecked use of groundwater, and represented a political response to decades of experience with and observations of the effects of groundwater pumping on surface water. Because of this fundamental change in the institutions that balance surface and groundwater that it brought about, the passage of L.B. 962 can be considered evidence of some movement toward triple-loop learning, or system transformation (Pahl-Wostl 2009). However, continued reliance 
on agricultural irrigation as a drought mitigation measure may leave the PRW vulnerable to future multiyear drought and suggests that deeper learning is yet to be achieved.

Some components of Pahl-Wostl's evaluation rubric were more directly applicable than others to the data that we had collected. Our history rooted in media stories did not provide, for example, much detail on the distribution of financial investment in infrastructure in the PRW; extensive additional data collection and analysis would have been necessary to make a detailed assessment. An advantage of using a rubric such as this one is comparability across basins, but other methods of comparison may provide more basin-specific insights.

\section{SYNTHESIS AND CONCLUSIONS}

Our analysis shows how interacting coping strategies and governance mechanisms for dealing with water shortages implemented by actors at multiple scales (individual irrigators, municipal government, NRDs, state and federal agencies, and others) produce a system that managed to avert catastrophic impacts to livelihoods and domestic water supplies during severe drought in 2012. This governance system shows evidence of learning from recent drought experiences. Although the droughts of 2002 and 2012 imposed considerable stress on these systems, responses at a variety of spatial and institutional scales suggest a useful range of capability within the system. Drought in 2012 triggered state-imposed restrictions of surface water irrigation and, at a longer time scale, NRD-imposed restrictions on groundwater irrigation. The City of Lincoln's decision to tighten its belt and restrict outdoor watering until the end of the agricultural irrigation season effectively suppressed a potential source of intersectoral conflict (Fig. 5).

In agricultural regions of the PRW, we find a positive feedback of agricultural irrigation (Fig. 5), with concurrently increasing adoption of irrigation infrastructure, expansion of irrigated land, and a concomitant shift toward more water-intensive crops, as has been observed in other parts of the High Plains aquifer system (Hornbeck and Keskin 2014). Reliance on irrigation has led to substantial groundwater drawdown during drought in heavily agricultural areas, which may be more difficult to recover from in the future (Burbach and Joeckel 2006). However, we do not observe a shift to less water-intensive crops on nonirrigated land. Our agricultural evidence analyzed point to reliance on irrigation as the sole mechanism used to mitigate drought impacts, as is true in many other regions of the world (Varela-Ortega et al. 2011, Wei et al. 2011). It is notable that our media analysis found no substantial debate about the sustainability or vulnerability of an increasingly mono-cultural system focused on a water-intensive crop (corn). Although drought prompted dialogue and/or initiation of various measures to further protect urban water supplies, there was no apparent discussion of alternative cropping practices that could promote drought resilience by means other than irrigation. It is likely that the benefits of this system continued to outweigh the costs, at least in the short term. Policies and markets at the national and global levels tend to drive production, whereas water shortages and constraints on supply are experienced locally (Sivapalan et al. 2012). Any counterbalance to the prevailing pattern of crop choice may have to come from the federal level, which was the source of the energy and agricultural policies that shaped decisions to plant corn (Fausti 2015).
Despite this, we found that urban water use and population growth have not exacerbated intersectoral conflict with agricultural users, and instead cities may introduce a high flexibility of water use and adaptive capacity to buffer against agricultural losses during droughts (Fig. 5). Lincoln's de facto decision to make urban greenery a lower priority than agricultural production represents a novel type of relationship between urban and agricultural water users, in which outdoor urban water use represents a flexible water demand that can be rapidly curtailed to reduce potential conflict with other users. This is in direct contrast to the prevailing narrative in intersectoral water conflict literature, which assumes that urban water use is of higher value than agriculture (Molle and Berkoff 2009). The City of Lincoln's increasing population is counteracted by long-term conservation trends and decreasing per capita water use, and as such aggregate urban water use has slightly decreased while maintaining a constant level of greenness. Although urban water use increases during drought, we observe that urban water use can be rapidly reduced via water restrictions, and is up to 50 liters per capita per day lower during the 2012 drought than would be predicted given meteorological conditions. Although this curtailment led to short-term reductions in urban greenness, urban vegetation quickly rebounded after the end of the drought when restrictions were eased.

From this, we suggest that the observed urban adaptability, and particularly the flexibility in seasonal water use (Gober et al. 2016), in the face of drought represents a watershed-scale adaptive mechanism that reduces intersectoral conflict over water resources in the case of the PRW. However, the adaptability of domestic water use has hard limits, as evidenced by the Lower Elkhorn NRD's decision to curtail groundwater irrigation after domestic wells started drying up during the 2012 drought. Asking urban residents to conserve water to protect agricultural interests is a political decision, and the viability of this approach is contingent on variables such as commodity prices and land valuation and events such as legislation or changes in tax code that color the perceptions of relative hardships and benefits in agricultural and urban sectors. Drought in 2012 was, fortunately, a one-year event, and Lincoln's mandatory water restrictions only lasted for a little over a month. A multiyear drought and associated restrictions would test the system's ability to balance agricultural and urban water use. Furthermore, because both agricultural extent and farming practices as well as urban populations are relatively static in the PRW compared to rapidly changing watersheds such as those present in developing nations, additional research is needed to test under what conditions urban water use may represent a watershed-scale coping mechanism.

Our conclusions have significant implications for the future of the PRW and other mixed urban-agricultural watersheds worldwide, particularly in light of anticipated future changes in drought frequency and severity (Dai 2013, Trenberth et al. 2014). As a whole, we demonstrate that urban water use may represent a flexible use of water that can be more rapidly and effectively curtailed during drought conditions when compared to agricultural users. We also conclude that although the existing governance mechanisms appear to protect water supplies, excessive investment in cropping systems that are dependent on irrigation is a source of vulnerability in the long term. Our research also highlights the value and need to adopt an interdisciplinary approach and integrate multiple lines of 
evidence to address sustainability challenges related to water resource management in coupled socio-environmental systems (Van Loon et al. 2016a), in particular as they relate to unanticipated or indirect feedbacks between management, biophysical processes, and ecosystem services upon which society depends (Booth et al. 2016, Zipper et al. 2017).

Responses to this article can be read online at: http://www.ecologyandsociety.org/issues/responses. $\mathrm{php} / 9549$

\section{Acknowledgments:}

This work was supported by the National Socio-Environmental Synthesis Center (SESYNC) under funding received from the National Science Foundation DBI-1052875. The authors would particularly like to acknowledge support from Jonathan Kramer, Jo Johnson, and Nicole Motzer, as well as helpful discussions with Chloe Begg throughout the project. We thank Adam Berland for assistance gathering the EVI data, the Lincoln Water System for sharing water use data, and Christopher Kucharik for sharing gridded meteorological data. Comments from the editors and two anonymous reviewers greatly improved the quality of the manuscript. Mark Burbach, Xi Chen, Dominick Ciruzzi, Bethany Cutts, Steve Loheide, and Kim Scherber provided helpful feedback on earlier versions of this manuscript.

\section{LITERATURE CITED}

Allen, R. G., L. S. Pereira, D. Raes, and M. Smith. 1998. Crop evapotranspiration: guidelines for computing crop water requirements. United Nations Food and Agriculture Organization, Rome, Italy.

Alley, W. M. 1984. The Palmer Drought Severity Index: limitations and assumptions. Journal of Climate and Applied Meteorology 23(7):1100-1109. http://dx.doi.org/10.1175/1520-0450 (1984) $023<1100:$ TPDSIL $>2.0 . \mathrm{CO} ; 2$

Begueria, S., and S. M. Vicente-Serrano. 2013. SPEI: Calculation of the standardised precipitation-evapotranspiration index (version $R$ package version 1.6). https://CRAN.R-project.org/package= $\underline{\text { SPEI }}$

Beilin, R., T. Sysak, and S. Hill. 2012. Farmers and perverse outcomes: the quest for food and energy security, emissions reduction and climate adaptation. Global Environmental Change 22(2):463-471. http://dx.doi.org/10.1016/j.gloenvcha.2011.12.003

Bleed, A., and C. Hoffman Babbitt. 2015. Nebraska's natural resources districts: an assessment of a large-scale locally controlled water governance framework. Policy Report, Robert B. Daugherty Water for Food Institute, University of Nebraska, Lincoln, Nebraska, USA.

Booth, E. G., S. C. Zipper, S. P. Loheide II, and C. J. Kucharik. 2016. Is groundwater recharge always serving us well? Water supply provisioning, crop production, and flood attenuation in conflict in Wisconsin, USA. Ecosystem Services 21(Part A):153-165. http://dx.doi.org/10.1016/j.ecoser.2016.08.007
Boyer, J. S., and M. E. Westgate. 2004. Grain yields with limited water. Journal of Experimental Botany 55(407):2385-2394. http:// dx.doi.org/10.1093/jxb/erh219

Breyer, B., H. Chang, and G. H. Parandvash. 2012. Land-use, temperature, and single-family residential water use patterns in Portland, Oregon and Phoenix, Arizona. Applied Geography 35 (1-2):142-151. http://dx.doi.org/10.1016/j.apgeog.2012.06.012

Briffa, K. R., G. van der Schrier, and P. D. Jones. 2009. Wet and dry summers in Europe since 1750: evidence of increasing drought. International Journal of Climatology 29(13):1894-1905. http://dx.doi.org/10.1002/joc.1836

Burbach, M. E., and R. M. Joeckel. 2006. A delicate balance: rainfall and groundwater in Nebraska during the 2000-2005 drought. Great Plains Research 16(1):5-16.

Çakir, R. 2004. Effect of water stress at different development stages on vegetative and reproductive growth of corn. Field Crops Research 89(1):1-16. http://dx.doi.org/10.1016/j.fcr.2004.01.005

Chen, T., G. R. Werf, R. A. M. Jeu, G. Wang, and A. J. Dolman. 2013. A global analysis of the impact of drought on net primary productivity. Hydrology and Earth System Sciences 17 (10):3885-3894. http://dx.doi.org/10.5194/hess-17-3885-2013

Cohen, B. 2006. Urbanization in developing countries: current trends, future projections, and key challenges for sustainability. Technology in Society 28(1-2):63-80. http://dx.doi.org/10.1016/j. techsoc.2005.10.005

Condon, N., H. Klemick, and A. Wolverton. 2015. Impacts of ethanol policy on corn prices: a review and meta-analysis of recent evidence. Food Policy 51:63-73. http://dx.doi.org/10.1016/j. foodpol.2014.12.007

Coomes, P., T. Rockaway, J. Rivard, and B. Kornstein. 2010. North America residential water usage trends since 1992. Water Research Foundation, Denver, Colorado, USA.

Craig, R. K. 2010. Stationarity is dead - long live transformation: five principles for climate change adaptation law. Harvard Environmental Law Review 34:9-74.

Creswell, J. W. 2012. Qualitative inquiry and research design: choosing among five approaches. SAGE, Thousand Oaks, California, USA.

Dai, A. 2013. Increasing drought under global warming in observations and models. Nature Climate Change 3(1):52-58. http://dx.doi.org/10.1038/nclimate1633

Doell, P., and S. Siebert. 1999. A digital global map of irrigated areas, report A9901. University of Kassel, Kassel, Germany.

Doremus, H. 2001. Adaptive management, the Endangered Species Act, and the institutional challenges of new age environmental protection. Washburn Law Journal 41:50-89.

Droogers, P., and R. G. Allen. 2002. Estimating reference evapotranspiration under inaccurate data conditions. Irrigation and Drainage Systems 16(1):33-45. http://dx.doi.org/10.1023/ A:1015508322413

Fausti, S. W. 2015. The causes and unintended consequences of a paradigm shift in corn production practices. Environmental Science \& Policy 52:41-50. http://dx.doi.org/10.1016/j.envsci.2015.04.017 
Gato, S., N. Jayasuriya, and P. Roberts. 2007. Temperature and rainfall thresholds for base use urban water demand modelling. Journal of Hydrology 337(3-4):364-376. http://dx.doi.org/10.1016/ j.jhydrol.2007.02.014

Gober, P., R. Quay, and K. L. Larson. 2016. Outdoor water use as an adaptation problem: insights from North American cities. Water Resources Management 30(3):899-912. http://dx.doi. org/10.1007/s11269-015-1205-6

Grigg, N. S. 2014. The 2011-2012 drought in the United States: new lessons from a record event. International Journal of Water Resources Development 30(2):183-199. http://dx.doi. org/10.1080/07900627.2013.847710

Gunderson, L., and S. S. Light. 2006. Adaptive management and adaptive governance in the Everglades ecosystem. Policy Sciences 39(4):323-334. http://dx.doi.org/10.1007/s11077-006-9027-2

Hargreaves, G. H. 1994. Defining and using reference evapotranspiration. Journal of Irrigation and Drainage Engineering 120(6):1132-1139. http://dx.doi.org/10.1061/(ASCE) 0733-9437(1994)120:6(1132)

Hicks, N. 2012. City's water restrictions now mandatory; first time since 2002. Lincoln Journal-Star, 9 August.

Hiler, E. A., and R. N. Clark. 1971. Stress day index to characterize effects of water stress on crop yields. Transactions of the ASAE 14(4):0757-0761. http://dx.doi.org/10.13031/2013.38384

Hoffman, C., and S. Zellmer. 2013. Assessing institutional ability to support adaptive, integrated water resources management. Nebraska Law Review 91:805-865.

Hoffman Babbitt, C., M. Burbach, and L. Pennisi. 2015. A mixedmethods approach to assessing success in transitioning water management institutions: a case study of the Platte River Basin, Nebraska. Ecology and Society 20(1):54. http://dx.doi. org/10.5751/ES-07367-200154

Hornbeck, R., and P. Keskin. 2014. The historically evolving impact of the Ogallala Aquifer: agricultural adaptation to groundwater and drought. American Economic Journal-Applied Economics 6(1):190-219. http://dx.doi.org/10.1257/app.6.1.190

Huitema, D., E. Mostert, W. Egas, S. Moellenkamp, C. PahlWostl, and R. Yalcin. 2009. Adaptive water governance: assessing the institutional prescriptions of adaptive (co-)management from a governance perspective and defining a research agenda. Ecology and Society 14(1):26. http://dx.doi.org/10.5751/ES-02827-140126

Kendy, E., J. Wang, D. J. Molden, C. Zheng, C. Liu, and T. S. Steenhuis. 2007. Can urbanization solve inter-sector water conflicts? Insight from a case study in Hebei Province, North China Plain. Water Policy 9:75-93. http://dx.doi.org/10.2166/ wp.2007.046

Kenney, D. S., C. Goemans, R. Klein, J. Lowrey, and K. Reidy. 2008. Residential water demand management: lessons from Aurora, Colorado. Journal of the American Water Resources Association 44(1):192-207. http://dx.doi.org/10.1111/

j.1752-1688.2007.00147.x

Kenney, D. S., R. A. Klein, and M. P. Clark. 2004. Use and effectiveness of municipal water restrictions during drought in
Colorado. Journal of the American Water Resources Association 40(1):77-87. http://dx.doi.org/10.1111/j.1752-1688.2004.tb01011. $\underline{\mathrm{X}}$

Kiem, A. S. 2013. Drought and water policy in Australia: challenges for the future illustrated by the issues associated with water trading and climate change adaptation in the MurrayDarling Basin. Global Environmental Change 23(6):1615-1626. http://dx.doi.org/10.1016/j.gloenvcha.2013.09.006

Laukaitis, A. J. 2014. Irrigators dissatisfied with proposed groundwater rules for Dwight-Valparaiso-Brainard area. Lincoln Journal-Star, 9 January.

Lautze, J., S. de Silva, M. Giordano, and L. Sanford. 2011. Putting the cart before the horse: water governance and IWRM. Natural Resources Forum 35(1):1-8. http://dx.doi.org/10.1111/ j.1477-8947.2010.01339.x

Li, Y. 2013. Analysis of urban water use and urban consumptive water use in Nebraska - case study in the city of Lincoln, Grand Island and Sidney. Thesis. University of Nebraska, Lincoln, Nebraska, USA.

Maidment, D. R., and S.-P. Miaou. 1986. Daily water Use in nine cities. Water Resources Research 22(6):845-851. http://dx.doi. org/10.1029/WR022i006p00845

Mavromatis, T. 2007. Drought index evaluation for assessing future wheat production in Greece. International Journal of Climatology 27(7):911-924. http://dx.doi.org/10.1002/joc.1444

McDonald, R. I., P. Green, D. Balk, B. M. Fekete, C. Revenga, M. Todd, and M. Montgomery. 2011. Urban growth, climate change, and freshwater availability. Proceedings of the National Academy of Sciences of the United States of America 108 (15):6312-6317. http://dx.doi.org/10.1073/pnas.1011615108

McPhail, L. L., and B. A. Babcock. 2012. Impact of US biofuel policy on US corn and gasoline price variability. Energy 37 (1):505-513. http://dx.doi.org/10.1016/j.energy.2011.11.004

Milly, P. C. D., J. Betancourt, M. Falkenmark, R. M. Hirsch, Z. W. Kundzewicz, D. P. Lettenmaier, and R. J. Stouffer. 2008. Stationarity is dead: whither water management? Science 319 (5863):573-574. http://dx.doi.org/10.1126/science.1151915

Mini, C., T. S. Hogue, and S. Pincetl. 2015. The effectiveness of water conservation measures on summer residential water use in Los Angeles, California. Resources, Conservation and Recycling 94:136-145. http://dx.doi.org/10.1016/j.resconrec.2014.10.005

Molle, F., and J. Berkoff. 2009. Cities vs. agriculture: a review of intersectoral water re-allocation. Natural Resources Forum 33 (1):6-18. http://dx.doi.org/10.1111/j.1477-8947.2009.01204.x

Motew, M. M., and C. J. Kucharik. 2013. Climate-induced changes in biome distribution, NPP, and hydrology in the Upper Midwest U.S.: a case study for potential vegetation. Journal of Geophysical Research: Biogeosciences 118(1):248-264. http://dx. doi.org/10.1002/jgrg.20025

Norton, L. R. 2016. Is it time for a socio-ecological revolution in agriculture? Agriculture, Ecosystems \& Environment 235:13-16. http://dx.doi.org/10.1016/j.agee.2016.10.007 
Orsini, F., R. Kahane, R. Nono-Womdim, and G. Gianquinto. 2013. Urban agriculture in the developing world: a review. Agronomy for Sustainable Development 33(4):695-720. http://dx. doi.org/10.1007/s13593-013-0143-Z

Ostrom, E. 1990. Governing the commons: the evolution of institutions for collective action. Cambridge University Press, Cambridge, UK. http://dx.doi.org/10.1017/CBO9780511807763

Ostrom, E. 2009. A general framework for analyzing sustainability of social-ecological systems. Science 325 (5939):419-422. http://dx.doi.org/10.1126/science.1172133

Ozdogan, M., and G. Gutman. 2008. A new methodology to map irrigated areas using multi-temporal MODIS and ancillary data: an application example in the continental US. Remote Sensing of Environment 112(9):3520-3537. http://dx.doi.org/10.1016/j.rse.2008.04.010

Pahl-Wostl, C. 2007. Transitions towards adaptive management of water facing climate and global change. Water Resources Management 21(1):49-62. http://dx.doi.org/10.1007/s11269-006-9040-4

Pahl-Wostl, C. 2009. A conceptual framework for analysing adaptive capacity and multi-level learning processes in resource governance regimes. Global Environmental Change 19(3):354-365. http://dx.doi.org/10.1016/j.gloenvcha.2009.06.001

Pahl-Wostl, C., G. Holtz, B. Kastens, and C. Knieper. 2010. Analyzing complex water governance regimes: the management and transition framework. Environmental Science \& Policy 13 (7):571-581. http://dx.doi.org/10.1016/j.envsci.2010.08.006

Pearson, L. J., L. Pearson, and C. J. Pearson. 2010. Sustainable urban agriculture: stocktake and opportunities. International Journal of Agricultural Sustainability 8(1-2):7-19. http://dx.doi. org/10.3763/ijas.2009.0468

Potopová, V., P. Štěpánek, M. Možný, L. Türkott, and J. Soukup. 2015. Performance of the standardised precipitation evapotranspiration index at various lags for agricultural drought risk assessment in the Czech Republic. Agricultural and Forest Meteorology 202:26-38. http://dx.doi.org/10.1016/j.agrformet.2014.11.022

Ragin, C. C. 1992. "Casing" and the process of social inquiry. Pages 217-226 in C. C. Ragin and H. S. Becker, editors. What is a case?: exploring the foundations of social inquiry. Cambridge University Press, New York, New York, USA.

Ramankutty, N., J. A. Foley, and N. J. Olejniczak. 2002. People on the land: changes in global population and croplands during the 20th century. AMBIO: A Journal of the Human Environment 31(3):251-257. http://dx.doi.org/10.1579/0044-7447-31.3.251

Saurí, D. 2013. Water conservation: theory and evidence in urban areas of the developed world. Annual Review of Environment and Resources 38(1):227-248. http://dx.doi.org/10.1146/annurevenviron-013113-142651

Scanlon, B. R., B. L. Ruddell, P. M. Reed, R. I. Hook, C. Zheng, V. C. Tidwell, and S. Siebert. 2017. The food-energy-water nexus: transforming science for society. Water Resources Research 53 (5):3550-3556. http://dx.doi.org/10.1002/2017WR020889

Seidl, R., and R. Barthel. 2017. Linking scientific disciplines: hydrology and social sciences. Journal of Hydrology 550:441-452. http://dx.doi.org/10.1016/j.jhydrol.2017.05.008
Shanahan, T. M., J. T. Overpeck, K. J. Anchukaitis, J. W. Beck, J. E. Cole, D. L. Dettman, J. A. Peck, C. A. Scholz, and J. W. King. 2009. Atlantic forcing of persistent drought in West Africa. Science 324(5925):377-380. http://dx.doi.org/10.1126/science.1166352

Sheffield, J., E. F. Wood, and M. L. Roderick. 2012. Little change in global drought over the past 60 years. Nature 491 (7424):435-438. http://dx.doi.org/10.1038/nature11575

Simelton, E., E. D. G. Fraser, M. Termansen, P. M. Forster, and A. J. Dougill. 2009. Typologies of crop-drought vulnerability: an empirical analysis of the socio-economic factors that influence the sensitivity and resilience to drought of three major food crops in China (1961-2001). Environmental Science \& Policy 12 (4):438-452. http://dx.doi.org/10.1016/j.envsci.2008.11.005

Sivapalan, M., H. H. G. Savenije, and G. Blöschl. 2012. Sociohydrology: a new science of people and water. Hydrological Processes 26(8):1270-1276. http://dx.doi.org/10.1002/hyp.8426

Srinivasan, V., K. C. Seto, R. Emerson, and S. M. Gorelick. 2013. The impact of urbanization on water vulnerability: a coupled human-environment system approach for Chennai, India. Global Environmental Change 23(1):229-239. http://dx.doi.org/10.1016/ j.gloenvcha.2012.10.002

Stake, R. E. 2005. Qualitative case studies. Pages 443-466 in N. K. Denzin and Y. S. Lincoln, editors. The SAGE handbook of qualitative research. Third edition. SAGE, Thousand Oaks, California, USA.

Sate of California. 2015. Drought update. Sacramento, California, USA.

Sun, L., S. W. Mitchell, and A. Davidson. 2012. Multiple drought indices for agricultural drought risk assessment on the Canadian prairies. International Journal of Climatology 32(11):1628-1639. http://dx.doi.org/10.1002/joc. 2385

Tan, P.-L., K. H. Bowmer, and J. Mackenzie. 2012. Deliberative tools for meeting the challenges of water planning in Australia. Journal of Hydrology 474:2-10. http://dx.doi.org/10.1016/j. jhydrol.2012.02.032

Thebo, A. L., P. Drechsel, and E. F. Lambin. 2014. Global assessment of urban and peri-urban agriculture: irrigated and rainfed croplands. Environmental Research Letters 9(11):114002. http://dx.doi.org/10.1088/1748-9326/9/11/114002

Trenberth, K. E., A. Dai, G. van der Schrier, P. D. Jones, J. Barichivich, K. R. Briffa, and J. Sheffield. 2014. Global warming and changes in drought. Nature Climate Change 4(1):17-22. http:// dx.doi.org/10.1038/nclimate2067

U.S. Census Bureau. 2017. City and town population totals datasets: 2010-2016. U.S. Census Bureau, Washington, D.C., USA. [online] URL: https://www.census.gov/data/datasets/2016/ demo/popest/total-cities-and-towns.html

U.S. Department of Agriculture (USDA). 2014. Nebraska: 2014 state agricultural overview. USDA National Agricultural Statistics Service, Washington, D.C., USA.

Van Loon, A. F., T. Gleeson, J. Clark, A. I. J. M. Van Dijk, K. Stahl, J. Hannaford, G. Di Baldassarre, A. J. Teuling, L. M. Tallaksen, R. Uijlenhoet, D. M. Hannah, J. Sheffield, M. 
Svoboda, B. Verbeiren, T. Wagener, S. Rangecroft, N. Wanders, and H. A. J. Van Lanen. 2016a. Drought in the Anthropocene. Nature Geoscience 9(2):89-91. http://dx.doi.org/10.1038/ngeo2646

Van Loon, A. F., K. Stahl, G. Di Baldassarre, J. Clark, S. Rangecroft, N. Wanders, T. Gleeson, A. I. J. M. Van Dijk, L. M. Tallaksen, J. Hannaford, R. Uijlenhoet, A. J. Teuling, D. M. Hannah, J. Sheffield, M. Svoboda, B. Verbeiren, T. Wagener, and H. A. J. Van Lanen. 2016b. Drought in a human-modified world: reframing drought definitions, understanding, and analysis approaches. Hydrology and Earth System Sciences 20 (9):3631-3650. http://dx.doi.org/10.5194/hess-20-3631-2016

Vano, J. A., N. Voisin, L. Cuo, A. F. Hamlet, M. M. Elsner, R. N. Palmer, A. Polebitski, and D. P. Lettenmaier. 2010. Climate change impacts on water management in the Puget Sound region, Washington State, USA. Climatic Change 102(1-2):261-286. http://dx.doi.org/10.1007/s10584-010-9846-1

Varela-Ortega, C., I. Blanco-Gutiérrez, C. H. Swartz, and T. E. Downing. 2011. Balancing groundwater conservation and rural livelihoods under water and climate uncertainties: an integrated hydro-economic modeling framework. Global Environmental Change 21(2):604-619. http://dx.doi.org/10.1016/j.gloenvcha.2010.12.001

Vicente-Serrano, S. M., S. Beguería, and J. I. López-Moreno. 2009. A multiscalar drought index sensitive to global warming: the Standardized Precipitation Evapotranspiration Index. Journal of Climate 23(7):1696-1718. http://dx.doi. org/10.1175/2009JCLI2909.1

Vicente-Serrano, S. M., C. Gouveia, J. Julio Camarero, S. Beguería, R. Trigo, J. I. López-Moreno, C. Azorin-Molina, E. Pasho, J. Lorenzo-Lacruz, J. Revuelto, E. Morán-Tejeda, and A. Sanchez-Lorenzo. 2013. Response of vegetation to drought timescales across global land biomes. Proceedings of the National Academy of Sciences of the United States of America 110(1):52-57. http://dx.doi.org/10.1073/pnas. 1207068110

Vicente-Serrano, S. M., G. Van der Schrier, S. Beguería, C. AzorinMolina, and J.-I. Lopez-Moreno. 2015. Contribution of precipitation and reference evapotranspiration to drought indices under different climates. Journal of Hydrology 526:42-54. http:// dx.doi.org/10.1016/j.jhydrol.2014.11.025

Wada, Y., L. P. H. van Beek, and M. F. P. Bierkens. 2012. Nonsustainable groundwater sustaining irrigation: a global assessment. Water Resources Research 48(6):W00L06. http://dx. doi.org/10.1029/2011WR010562

Wanders, N., and Y. Wada. 2015. Human and climate impacts on the 21 st century hydrological drought. Journal of Hydrology 526:208-220. http://dx.doi.org/10.1016/j.jhydrol.2014.10.047

Wei, Y., J. Langford, I. R. Willett, S. Barlow, and C. Lyle. 2011. Is irrigated agriculture in the Murray Darling Basin well prepared to deal with reductions in water availability? Global Environmental Change 21(3):906-916. http://dx.doi.org/10.1016/j.gloenvcha.2011.04.004

Wilhelmi, O. V., and D. A. Wilhite. 2002. Assessing vulnerability to agricultural drought: a Nebraska case study. Natural Hazards 25(1):37-58. http://dx.doi.org/10.1023/A:1013388814894

Wu, H., K. G. Hubbard, and D. A. Wilhite. 2004. An agricultural drought risk-assessment model for corn and soybeans.
International Journal of Climatology 24(6):723-741. http://dx.doi. org/10.1002/joc. 1028

Yin, R. K. 2013. Case study research: design and methods. Fifth edition. SAGE, Thousand Oaks, California, USA.

Young, A. R., M. E. Burbach, and L. M. Howard. 2015. Nebraska statewide groundwater-level monitoring report. Institute of Agriculture and Natural Resources, University of NebraskaLincoln, Lincoln, Nebraska, USA.

Zipper, S. C., and S. P. Loheide. 2014. Using evapotranspiration to assess drought sensitivity on a subfield scale with HRMET, a high resolution surface energy balance model. Agricultural and Forest Meteorology 197:91-102. http://dx.doi.org/10.1016/j. agrformet.2014.06.009

Zipper, S. C., J. Qiu, and C. J. Kucharik. 2016. Drought effects on US maize and soybean production: spatiotemporal patterns and historical changes. Environmental Research Letters 11(9):094021. http://dx.doi.org/10.1088/1748-9326/11/9/094021

Zipper, S. C., M. E. Soylu, E. G. Booth, and S. P. Loheide II. 2015. Untangling the effects of shallow groundwater and soil texture as drivers of subfield-scale yield variability. Water Resources Research 51(8):6338-6358. http://dx.doi.org/10.1002/2015WR017522

Zipper, S. C., M. E. Soylu, C. J. Kucharik, and S. P. Loheide II. 2017. Quantifying indirect groundwater-mediated effects of urbanization on agroecosystem productivity using MODFLOWAgroIBIS (MAGI), a complete critical zone model. Ecological Modelling 359:201-219. http://dx.doi.org/10.1016/j.ecolmodel.2017.06.002 


\section{APPENDIX 1: \\ City of Lincoln Water Conservation Messaging, 2000-2015}

Table A1.1 City of Lincoln water conservation messaging.

\begin{tabular}{|l|l|}
\hline Year & Messaging \\
\hline 2000 & 1 \\
\hline 2001 & 1 \\
\hline 2002 & 3 \\
\hline 2003 & 2 \\
\hline 2004 & 2 \\
\hline 2005 & 2 \\
\hline 2006 & 2 \\
\hline 2007 & 2 \\
\hline 2008 & 2 \\
\hline 2009 & 2 \\
\hline 2010 & 1 \\
\hline 2011 & 1 \\
\hline 2012 & 3 \\
\hline 2013 & 1 \\
\hline 2014 & 1 \\
\hline
\end{tabular}

Table A1.1 legend:

$0=$ no water conservation messages

$1=$ general endorsement of conservation

$2=$ official voluntary conservation, following odd-even watering schedules.

$3=$ mandatory conservation, following odd-even watering schedules

This data is assembled from the City of Lincoln Mayor's Office online archive of press releases (https://lincoln.ne.gov/CITY/mayor/media/index.htm); press releases are linked below. 


\section{Appendix 1 References}

City of Lincoln, Mayor's Office. May 15, 2014. Mayor not recommending water restrictions; residents encouraged to follow good conservation practices. https://lincoln.ne.gov/CITY/mayor/media/2014/051514c.htm

City of Lincoln, Mayor's Office. July 23, 2013. Mayor urges water conservation; watering restrictions NOT in effect at this time. https://lincoln.ne.gov/CITY/mayor/media/2013/072313a.htm

City of Lincoln, Mayor's Office. May 16, 2013. Mayor not recommending water restrictions; residents encouraged to follow good conservation practices. https://lincoln.ne.gov/CITY/mayor/media/2013/051613.htm

City of Lincoln, Mayor's Office. Sep 13, 2012. Water restrictions now voluntary; Mayor to consider pardons for those ticketed for watering violations. https://lincoln.ne.gov/CITY/mayor/media/2012/091312.htm

City of Lincoln, Mayor's Office. Sep 6, 2012. Mandatory water restrictions remain in effect; City asks for help watering young street trees. https://lincoln.ne.gov/CITY/mayor/media/2012/090612.htm

City of Lincoln, Mayor's Office. Aug 24, 2012. Mayor urges residents to use less water. https://lincoln.ne.gov/CITY/mayor/media/2012/082412.htm

City of Lincoln, Mayor's Office. Aug 19, 2012. Water restriction violators will be ticketed, beginning Monday; City officials to consider more stringent restrictions Thursday. https://lincoln.ne.gov/CITY/mayor/media/2012/081912.htm

City of Lincoln, Mayor's Office. Aug 9, 2012. Mandatory water restrictions now in effect. https://lincoln.ne.gov/CITY/mayor/media/2012/080912.htm

City of Lincoln, Mayor's Office. Aug 3, 2012. Mayor sets new goal for water conservation. https://lincoln.ne.gov/CITY/mayor/media/2012/080312.htm

City of Lincoln, Mayor's Office. July 26, 2012. Mayor urges voluntary water conservation. https://lincoln.ne.gov/CITY/mayor/media/2012/072612.htm

City of Lincoln, Mayor's Office. July 11, 2012. Mayor calls for voluntary water conservation. https://lincoln.ne.gov/CITY/mayor/media/2012/071112.htm

City of Lincoln, Mayor's Office. July 9, 2012. Parks and Rec asks for help in watering street trees. https://lincoln.ne.gov/CITY/mayor/media/2012/070912.htm

City of Lincoln, Mayor's Office. May 17, 2012. Mayor not recommending watering restrictions. https://lincoln.ne.gov/CITY/mayor/media/2012/051712.htm

City of Lincoln, Mayor's Office. May 5, 2011. Mayor not recommending watering restrictions. https://lincoln.ne.gov/CITY/mayor/media/2011/050511.htm

City of Lincoln, Mayor's Office. May 20, 2010. Mayor says city water supply in good shape. https://incoln.ne.gov/city/mayor/media/2010/052010a.htm

City of Lincoln, Mayor's Office. May 7, 2009. Mayor calls for voluntary water conservation. https://lincoln.ne.gov/city/mayor/media/2009/050709a.htm

City of Lincoln, Mayor's Office. March 4, 2008. Mayor says continued water conservation needed. https://lincoln.ne.gov/city/mayor/media/2008/030408b.htm

City of Lincoln, Mayor's Office. May 22, 2008. Mayor calls for voluntary water conservation. https://lincoln.ne.gov/city/mayor/media/2008/052208a.htm

City of Lincoln, Mayor's Office. July 23, 2007. Mayor calls for continued voluntary water conservation. https://lincoln.ne.gov/city/mayor/media/2007/072307.htm

City of Lincoln, Mayor's Office. May 10, 2007. Mayor calls for voluntary water conservation. https://lincoln.ne.gov/city/mayor/media/2007/051007b.htm

City of Lincoln, Mayor's Office. Aug 7, 2006. City to continue voluntary water restrictions; water officials will continue to monitor usage and Platte River flows. https://lincoln.ne.gov/city/mayor/media/2006/080706.htm

City of Lincoln, Mayor's Office. Aug 3, 2006. Mayor issues outdoor water usage warning. https://lincoln.ne.gov/city/mayor/media/2006/080306.htm

City of Lincoln, Mayor's Office. July 28, 2006. Outdoor water usage alert. https://lincoln.ne.gov/city/mayor/media/2006/072806.htm

City of Lincoln, Mayor's Office. July 14, 2006. Mayor urges public to conserve water. https://lincoln.ne.gov/city/mayor/media/2006/071406.htm 
City of Lincoln, Mayor's Office. May 18, 2006. Mayor calls for voluntary water conservation. https://lincoln.ne.gov/city/mayor/media/2006/051806.htm

City of Lincoln, Mayor's Office. July 15, 2005. Public urged to conserve water. https://lincoln.ne.gov/city/mayor/media/2005/071505.htm

City of Lincoln, Mayor's Office. May 19, 2005. Mayor institutes voluntary watering plan; Mayor calls for continued water conservation. https://lincoln.ne.gov/city/mayor/media/2005/051905a.htm

City of Lincoln, Mayor's Office. Dec 6, 2004. Water system suggests year-round outdoor water conservation; Mayor directs task force to study suggestion. https://lincoln.ne.gov/city/mayor/media/2004/120604.htm

City of Lincoln, Mayor's Office. June 11, 2004. Mayor encourages continued outdoor water conservation efforts; voluntary water restrictions continue. https://lincoln.ne.gov/city/mayor/media/2004/061104.htm

City of Lincoln, Mayor's Office. April 8, 2004. Mayor asks for voluntary water conservation. https://lincoln.ne.gov/city/mayor/media/2004/040804.htm

City of Lincoln, Mayor's Office. July 31, 2003. Mayor says continued water conservation is important. https://lincoln.ne.gov/city/mayor/media/2003/073103.htm

City of Lincoln, Mayor's Office. July 25, 2003. Mayor asks for continued observance of voluntary outside water conservation measures. https://lincoln.ne.gov/city/mayor/media/2003/072503.htm

City of Lincoln, Mayor's Office. April 1, 2003. City begins voluntary water conservation today. https://lincoln.ne.gov/city/mayor/media/2003/040103.htm

City of Lincoln, Mayor's Office, Mar 14, 2003. Revised conservation plan changes watering schedule. https://lincoln.ne.gov/city/mayor/media/2003/031403.htm

City of Lincoln, Mayor's Office, Sep 5, 2002. Mandatory water restrictions lifted; mayor asks for voluntary measures to be followed. https://lincoln.ne.gov/city/mayor/media/2002/090502.htm

City of Lincoln, Mayor's Office. Aug 21, 2002. Mandatory water restrictions to continue. https://lincoln.ne.gov/city/mayor/media/2002/082102.htm

City of Lincoln, Mayor's Office. Aug 2, 2002. Daily water use average meeting goal; city increasing use of nondrinkable water. https://lincoln.ne.gov/city/mayor/media/2002/080202a.htm

City of Lincoln, Mayor's Office. July 26, 2002. Mayor thanks residents for drop in water usage; mandatory restrictions remain in effect. https://lincoln.ne.gov/city/mayor/media/2002/072602b.htm

City of Lincoln, Mayor's Office. July 22, 2002. Mayor says daily water usage over 70 million gallons may prompt additional mandatory restrictions. https://lincoln.ne.gov/city/mayor/media/2002/072202.htm

City of Lincoln, Mayor's Office. July 19, 2002. Mayor institutes mandatory water restrictions. https://lincoln.ne.gov/city/mayor/media/2002/071902.htm

City of Lincoln, Mayor's Office. July 9, 2002. Voluntary water restrictions still in effect. https://incoln.ne.gov/city/mayor/media/2002/070902.htm

City of Lincoln, Mayor's Office. July 5, 2002. Mayor institutes voluntary odd-even watering plan; Parks and Recreation Department taking conservation measures. https://incoln.ne.gov/city/mayor/media/2002/070502.htm

City of Lincoln, Mayor's Office. June 25, 2002. Mayor urges citizens to conserve water; citizens asked to voluntarily save water to avoid mandatory measures. https://lincoln.ne.gov/city/mayor/media/2002/062502.htm

City of Lincoln, Mayor's Office. May 22, 2002. Mayor urges water conservation, praises project coordination. https://lincoln.ne.gov/city/mayor/media/2002/052302.htm

City of Lincoln, Mayor's Office. July 19, 2001. Mayor encourages water and energy conservation. https://lincoln.ne.gov/city/mayor/media/2002/052302.htm

City of Lincoln, Mayor's Office. September 2000. Lincoln Water System has record year. https://lincoln.ne.gov/city/mayor/media/2000/092100.htm 


\section{APPENDIX 2: \\ History and institutional structure of water governance in the Platte River Watershed}

Nebraska's surface water, like that of most western states, is managed via the legal doctrine of prior appropriation, which allocates water based on a "first in time, first in right" approach. The state's Department of Natural Resources is charged with administering surface water, issuing permits and tracking usage, and, in times of shortage, notifying junior rights holders that they must cease withdrawals to protect supplies for senior or higher priority uses (Hoffman and Zellmer 2013, Bleed and Hoffman Babbitt 2015). A rationale for the prior appropriation system is that in dry years in arid regions, sharing water equally is likely to result in no one having enough (Bleed and Hoffman Babbitt 2015). Nebraska also prioritizes water use, ranking domestic use first, followed by agriculture second and manufacturing third, but to exercise a preference over senior rights, a preferred user would have to compensate senior rights holders (Hoffman and Zellmer 2013). The Platte River Recovery Implementation Program (PRRIP), established by an interstate cooperative agreement in 1997, protects instream flows for endangered species in the central Platte River (PRRIP, platteriverprogram.org).

Historic accounts of changes to water policy in Nebraska cite drought as a driver of change in some cases, although it may take years of political effort to develop, pass and implement new legislation. Bleed and Hoffman Babbitt (2015) also emphasize the role that leadership and political will have played in passing key water laws in Nebraska. In general, changes to Nebraska water governance over the past several decades represent additional layers of control and accountability. Rarely if ever have changes undone previous policy; rather, they add authority, responsibility and accountability.

In that vein, Nebraska's NRDs were created in 1972 to manage water, soil, and other natural resources, with boundaries roughly corresponding to watersheds, consolidating 154 single-purpose districts across the state (Hoffman and Zellmer 2013, Bleed and Hoffman Babbitt 2015). The Groundwater Management Act of 1975 gave NRDs authority to establish special management areas to protect groundwater, but stopped short of requiring that surface and groundwater be managed conjunctively (Hoffman and Zellmer 2013).

In 2004, L.B. 962 mandated that surface and groundwater be managed conjunctively, and designated some western basins within the state as fully or over-appropriated (Bleed and Hoffman Babbitt 2015). NRDs managing fully and over-appropriated basins are required to work with the state's Department of Natural Resources to create and implement integrated water management plans (IMPs), including "Clear goals and objectives with a purpose of sustaining a balance between water uses and water supplies so that the economic viability, social and environmental health, safety, and welfare of the river basin, subbasin, or reach can be achieved and maintained for both the near term and the long term" (Neb. Rev. Stat., 46-715). IMPs must include a process for gathering and using the best available data on surface and groundwater and must identify surface and groundwater controls. IMPs also include procedures for annual evaluations of water availability, the basis for management actions in the coming year. These annual assessments are based on multiple data sources and modeling by the State of Nebraska (Ostdiek 2009). Key management tools used by NRDs to regulate groundwater in the Platte 
River Basin are limits on how much water irrigators can pump and moratoria on new wells (Nebraska Association of NRDs, 2014). The IMP process must include consultation with stakeholders, including municipalities (Hoffman and Zellmer 2013).

The mechanisms that prompt negative feedback in this managed system occur at different time scales for surface and groundwater. The effects of drought show up relatively quickly in soil moisture and surface water, but may take years to fully register in groundwater. Language used repeatedly in the state's annual evaluations of hydrologically connected basins says "the test of looking at the sufficiency of streamflow to satisfy a junior surface water right is like a canary in a coal mine; the junior water rights act as an alarm system signaling that the stream and the hydrologically connected ground water aquifers are both fully appropriated" (Nebraska $2015 \mathrm{p}$. 2) Ongoing groundwater monitoring shows that the water table typically drops after drought years, but may recover to pre-drought levels in subsequent years (Young et al. 2015).

Previous researchers have evaluated aspects of Nebraska's method of integrated management of surface and groundwater from both adaptive management and common pool governance perspectives. Hoffman and Zellmer (2013) assessed the capacity of Nebraska's groundwater management institutions to implement adaptive management, which incorporates experimentation and acknowledges that the outcomes of environmental management decisions can't always be predicted. A summary of their results pertaining to four criteria established by Doremus (2001) is shown in Table A2.1.

Table A2.1 Assessment of adaptive management capacity of Nebraska's water management institutions.

\section{Tailoring the strategy to the problem}

NRDs are established roughly along watershed boundaries and structured to address local issues. However, planning to address larger-scale issues is voluntary in basins not designated fully or over-appropriated.

\section{Ensuring accountability and enforceability}

NRDs have a scope of authority to make a range of pertinent resource-management decisions, including taxation. This represents true local control, which is one of the key attributes of successful management of common pool resources. There is a perception that locally elected boards lean toward protecting their own or their neighbors' agricultural interests, but the IMP requirement to work with the state annually to assess water supplies serves as a counter-balance.

\section{Promoting directed learning}

IMPs include processes for monitoring surface and groundwater levels, and management actions in over-appropriated basins involving more than one NRD must be evaluated each year. The state and many NRDs have technical staff that collaborate on monitoring, modeling and related research. But some NRDs are missing data collection opportunities by not requiring meters on wells.

\section{Sustainable funding}

NRDs have a variety of taxing options, but in some cases, their tax base is tied to irrigated acreage, which could serve as a disincentive to reduce reliance on irrigation. Bleed and Hoffman Babbitt (2015) noted that NRDs with urban areas benefit from higher tax bases.) 
A separate analysis of the effectiveness of Nebraska's NRDs drew from Ostrom's eight design principles of common pool resource governance (Ostrom 1990). Hoffman Babbitt et al. (2015) conducted an extensive mixed-methods assessment of the IMP process in the five Nebraska NRDs that include the over-appropriated parts of the Platte River Basin. Interviews with 35 stakeholders involved in aspects of water use and regulation elicited seven additional criteria for successful water management. A subsequent survey of surface and groundwater users on all 15 principles found strongest concurrence that the benefits from using water resources outweigh the costs, and that sufficient knowledge exists to manage surface and groundwater. The researchers found that the newly-implemented system generally seems to be working and is a good start, but stakeholders representing municipal, environmental or surface water interests felt that their views took a backseat to agricultural interests. They also recommended that IMPs and coordination with the state be required for all NRDs, and that basin-wide planning be undertaken. Bleed and Hoffman Babbitt (2015) added substantial historic detail and contextual interpretation to elaborate on the findings of the mixed-methods research.

\section{Appendix 2 References}

Bleed, A., and C. Hoffman Babbitt. 2015. Nebraska's Natural Resources Districts: An Assessment of a Large-Scale Locally Controlled Water Governance Framework. Policy Report, Robert B. Daugherty Water for Food Institute, University of Nebraska, Lincoln NE.

Doremus, H. 2001. Adaptive Management, the Endangered Species Act, and the Institutional Challanges of New Age Environmental Protection. Washburn Law Journal 41:50-89.

Hoffman Babbitt, C., M. Burbach, and L. Pennisi. 2015. A mixed-methods approach to assessing success in transitioning water management institutions: a case study of the Platte River Basin, Nebraska. Ecology and Society 20(1).

Hoffman, C., and S. Zellmer. 2013. Assessing Institutional Ability to Support Adaptive, Integrated Water Resources Management. Nebraska Law Review 91:805-865.

Nebraska, S. of. 2015. Basic Assumptions Used in the Development of the Department of Natural Resources Proposed Method to Determine Whether a Stream and the Hydrologically Connected Ground Water Aquifers Are Fully Appropriated. Appendix F, Annual evaluation of availability of hydrologically connected water supplies. Page http://dnr.ne.gov/media/iwm/pdf/2015AnnualReport/2015_appendixF.pdf.

Ostdiek, A. 2009. Water Matters: A guide to integrated water management in Nebraska. Pages 1-4. Nebraska Department of Natural Resources.

Ostrom, E. 1990. Governing the Commons: The evolution of institutions for collective action. Cambridge University Press, Cambridge.

Young, A. R., M. E. Burbach, and L. M. Howard. 2015. Nebraska Statewide Groundwater-Level Monitoring Report. Institute of Agriculture and Natural Resources, University of Nebraska-Lincoln, Lincoln NE. 


\section{APPENDIX 3: \\ Detailed media analysis and drought narrative}

Analysis of news stories collected in the Drought Impact Reporter and related policy documents revealed several distinct instances from 2009 through mid-2015 of people encountering limits of water supplies in different parts of the Platte River system, including the Loup and Elkhorn basins, during drought. Some of those instances prompted new regulatory action or reexamination of existing regulatory mechanisms. Among those triggering reevaluation of governance mechanisms were conflict between upstream and downstream irrigators on the North Platte River, low flows that threatened the City of Lincoln's water supply, and water supplies for smaller rural water systems in the eastern part of the state. Other encounters with limits were presented in context of extreme measures to cope with extreme drought.

The water flowing from the North Platte River into the state's iconic Lake McConaughy was reduced after varying degrees of drought in the basin from 2000-2009 and years of increasing groundwater irrigation upstream, creating a shortfall for customers of the Central Nebraska Public Power and Irrigation District, which operates the dam and lake system and is the state's largest irrigation district. Central Nebraska Public Power and Irrigation District filed suit against the North Platte Natural Resources District in 2009, arguing that the district should further reduce the water allotment of irrigators in the Pumpkin Creek watershed. The lawsuit heightened the rhetoric about the importance of Lake McConaughy to the state. "Nebraska is on the edge of a historic natural resources disaster: Lake McConaughy drying up," was the description in the Omaha World-Herald when the suit was first filed (Hendee, Jan. 4, 2009). Later the paper observed that the lake contributes to recreation, wildlife habitat and power generation, and is "part of a system that is a source of water for four of Nebraska's five largest cities: Omaha, Lincoln, Grand Island and Kearney” (OWH, Sept. 6, 2009). An editorial questioned whether resolving water conflicts should be left to courts, and asked "how should the state's water laws be modified to ensure that the NRDs fulfill their duties not only to their irrigators but also to downstream water users and all state residents?" (OWH Sept. 20, 2009) The Nebraska Supreme Court ended up dismissing the case on the grounds that CNPPID did not have standing to appeal the NRD's decision, because CNPPID holds its water rights for the benefit of others (Kelly, 16; Nebraska Supreme Court, 2010). The Court also noted that it found CNPPID's rhetoric about Lake McConaughy to be "apocalyptic" beyond what the facts substantiated. In 2012, CNPPID officials said that inflows to Lake McConaughy had been falling for years, and that low inflows might be the new normal, due to increased irrigation development upstream (OWH, May 8, 2012). As drought developed during summer of 2012, the Grand Island Independent quoted a CNPPID official as saying the lake level was declining due to demands from downstream irrigators (July 5, 2012).

Nearly the entire state experienced intense drought in 2012. High corn and soybean prices led farmers with access to groundwater to drill more wells in 2012. The Department of Natural Resources said 1,105 new wells in 2012 were the most registered in a single year since 2005 (Hovey, Feb. 22, 2013). The drought triggered coping mechanisms, such as widespread curtailment of surface water irrigation during 2012, including about 200 irrigators in the Platte 
system shut off to preserve instream flow rights held by the Nebraska Game \& Parks Commission (Lincoln Journal-Star, July 13, 2012), and 45-minute blackouts in north-central Nebraska to accommodate the demand for power for irrigation systems (OWH July 25, 2012). A retired farmer recalled that even during the Dust Bowl years of the 1930s, the creek on his family farm never dried up, but it did in 2012 (Grand Island Independent, Sept. 23, 2012). The Dust Bowl was a historic drought on the Great Plains, exacerbated by overly aggressive plowing, that drove many farmers off their land and led to the formation of the U.S. Department of Agriculture's Soil Conservation Service, now the Natural Resources Conservation Service.

Water levels fell below pumps in domestic wells and wells serving small communities throughout eastern Nebraska in 2012, and groundwater continued to show effects of drought in 2013, prompting NRDs to impose new limits in 2013 and 2014. Eighty-one municipal water systems had problems due to drought (Laukaitis, Nov. 30, 2012). The Lower Elkhorn NRD became the first in eastern Nebraska to impose allocations (limits) on irrigators after more than 100 domestic wells went dry (Hovey, Jan. 25, 2013); the Lower Platte North NRD created a special district with new rules limiting irrigation in areas where aquifers had large drops in pressure; and the Lower Platte South NRD created a special management area in 2014 that prohibited new irrigated acres and imposed a three-year allocation (Nebraska Association of Natural Resources Districts, 2014). Irrigators expressed objections at a public meeting, although local water suppliers expressed support and pointed to drought as a common enemy: "Greg Bouc, the water plant operator for Valparaiso, applauded the NRD for trying to make the changes, saying that in the past 30 years he has never seen the water table drop at the rate it has in the past year. 'The biggest enemy in this room is not the irrigators or municipalities, it's the drought,' Bouc said”' (Laukaitis, Jan. 9, 2014).

The City of Lincoln considered exerting its right to water in August 2012, but decided instead to tighten its belt for the sake of upstream irrigators. In 2012, facing record low flows in the Platte River near its wellfield in Ashland, the City of Lincoln imposed mandatory watering restrictions but opted not to exert its right to water being used for irrigation upstream. The mayor was quoted as saying, "We realize that agriculture is the economic backbone of this city and region, and this is a critical time for our ag producers" (Hicks, Aug. 9, 2012).

Although the city imposed conservation requirements, it also encouraged people to water new street trees during drought in 2012 (OWH, Sept. 5, 2012). The City of Lincoln ended up fast-tracking construction of an additional well, which was completed in 2014 (Lincoln JournalStar, Sept. 5, 2014). The city also developed a new system of "drought rates" to encourage conservation when voluntary or mandatory restrictions were in place (LJS, May 13, 2013), and allowing the city to issue civil penalties such as fines rather than misdemeanor citations for watering violations. Drought ended in 2013 as these measures were being approved, and they had not as of late 2015 been used because the area had remained drought-free. The Lincoln Water System Facilities Master Plan 2013 update (dated 2014) found that conditions similar to the very low flows that affected its well fields on the Platte in 2012 were likely to occur again before 2060, and that the city should begin taking steps in 2016 to find land for a well field along 
the Missouri River, which would diversify its water supply and tap into a more drought-resistant river.

Drought in 2012 raised larger questions about balancing urban and agricultural water needs. As one newspaper article reported, "The daily drought drama will end at some point. But it's also calling attention to an ongoing situation in which the growing populations of the state's two largest cities are competing for a finite water supply with irrigators in the Loup and Elkhorn river basins. Especially this year, the heavy irrigation pumping that keeps crops watered in dry times is cutting into surface flows downstream and into the saturation in adjacent well fields used by both Lincoln and Omaha." Observers speculated that in the future Lincoln might need to buy farmers' irrigation rights (Hovey, Aug. 4, 2012). Information also circulated about the value of agriculture and irrigation to Nebraska's economy. Drought in 2012 diminished the value of the state's corn crop by $\$ 240$ million, mainly affecting the 35 percent of the crop that is not irrigated, and one out of three jobs in the state depends on agriculture, according to a story that relied on the Nebraska Corn Board (Sholes, Dec. 5, 2012). The difference was based on a projected decline in production to 1.3 billion bushels, down from an average of 1.4 to 1.5 billion. The Nebraska Farm Bureau Federation commissioned a study that found that "the state's ability to irrigate through drought in 2012 was worth \$11 billion in agricultural output” (Hovey, July 24, 2013). Politicians also paid homage to the importance of agriculture in the state.

The Lower Platte South Natural Resources District completed a voluntary Integrated Management Plan in 2014, which is broader in scope than the mandated plans created by western NRDs. Among other things it identifies the needs to create an emergency drought plan, to consider urban growth and water needs, to explore options such as dry-year leasing that could prevent water administration (invoking rights to surface water), and to work with cities and others on water recycling and other new initiatives. (LPSNRD, 2014).

In 2015, the Lower Platte River Basin Coalition announced that seven NRDs and the state would create a plan to develop more of the "surplus" or "average excess supply" of water that flows from the Sandhills, which is also the margin that buffers the water supplies of Lincoln and Omaha during drought. The Sandhills, comprising much of north-central Nebraska, are remote, sparsely populated, and drain via the Loup Basin into the Platte River above the well fields that supply the City of Lincoln's water system. "As the coalition works to better define this balance, they will look for ways to economically manage for conditions that exist the vast majority of the time, while subsequently ensuring plans are in place for the infrequent extreme drought periods when there's a risk of Platte River supplies falling below demands," according to a press release from the Nebraska Association of Natural Resource Districts (WOWT, July, 21, 2015). 


\section{Appendix 3 References}

Grand Island (NE) Independent. 2012 Jul 5. Dry weather, irrigation cut Lake McConaughy level. Accessed July 5, 2012: http://www.theindependent.com/news/state/dry-weather-irrigation-cut-lake-mcconaughtlevel/article_9ef24da0-21b6-5efe-87c9-571875626f3a.html

Grand Island Independent. 2012 Sep 23. Nebraska farmers compare current, former droughts. Accessed Sept. 23, 2012: http://www.theindependent.com/news/state/nebraska-farmers-compare-current-formerdroughts/article_e19beee7-ab30-56bd-b5e8-beb49da0161a.html

Hendee, D. 2009 Jan 8. McConaughy's owner says water restrictions aren't enough. Omaha-World Herald. Accessed Jan. 8, 2009: http://www.omaha.com/index.php?u_page=2798\&u_sid=10532087

Hicks, N. 2012 Aug 9. City's water restrictions now mandatory; first time since 2002. Lincoln Journal-Star. Accessed Nov. 2, 2015: http://journalstar.com/news/local/city-s-water-restrictions-now-mandatory-firsttime-since/article_cd775717-3956-5735-a990-5bc4a38654ac.html

Hovey, A. 2012 Aug 4. Dry Platte River threatens Lincoln's water supply. Lincoln Journal-Star, Lincoln, Nebraska. Accessed Nov. 2, 2015: http://journalstar.com/news/local/dry-platte-river-threatens-lincoln-s-watersupply/article 07570764-78c2-5f7b-a0c4-8a15bb084356.html

Hovey, A. 2013 Jan 25. Board sets limits on water use by northeast Nebraska irrigators. Lincoln Journal-Star. Accessed Nov. 2, 2015: http://journalstar.com/news/state-and-regional/nebraska/board-sets-limits-onwater-use-by-northeast-nebraska-irrigators/article 6b25ec6c-0f46-5a32-89aa-2b2682350680.html

Hovey, A., 2013 Feb 22. New irrigation wells surged in drought year. Lincoln Journal-Star. Accessed Nov. 2, 2015: http://journalstar.com/news/state-and-regional/nebraska/new-irrigation-wells-surged-in-droughtyear/article_aa333aac-6093-5988-bd12-2803ac84509b.html

Hovey, A. 2013 Jul 24. Study: Irrigation saved billions in Nebraska. Lincoln Journal-Star, Lincoln, Nebraska. Accessed Nov. 2, 2015: http://journalstar.com/news/local/study-irrigation-saved-billions-innebraska/article_ac21c051-dcd9-5ed2-80f0-dd191938f042.html

Kelly, M. 2010 Sep. Nebraska's Evolving Water Law: Overview of Challenges \& Opportunities. Platte Institute for Economic Research. Policy Study. Omaha, Nebraska. https://www.heartland.org/sites/default/files/20100927_Kelly_Paper___FINAL.pdf

Laukaitis, A. 2012 Jul 13. State orders irrigators to stop pumping water. Lincoln Journal-Star. http://journalstar.com/news/state-and-regional/govt-and-politics/state-orders-irrigators-to-stop-pumpingwater/article_98391404-9487-50b1-9820-323a19f94f42.html

Laukaitis, A. 2012 Nov 30. No relief in sight from drought conditions; could become a multi-year event. Lincoln Journal-Star. Accessed Nov. 15, 2015: http://journalstar.com/news/state-and-regional/nebraska/no-relief-insight-from-drought-conditions-could-become-a/article_ea8db3fe-a1f1-5d52-9d4d-a1f5ff46afbc.html

Laukaitis, A. 2014 Jan 9. Irrigators dissatisfied with proposed groundwater rules for Dwight-Valparaiso-Brainard area. Lincoln Journal-Star. http://journalstar.com/news/local/irrigators-dissatisfied-with-proposedgroundwater-rules-for-dwight-valparaiso-brainard/article_18699e03-7e1d-5159-9efc-2865bb56e2a5.html

Hicks, N. 2013 May 13. Drought rates pass council; won't go into effect until emergency. Lincoln Journal-Star. Accessed Feb. 18, 2016: http://journalstar.com/news/local/govt-and-politics/drought-rates-pass-councilwon-t-go-into-effect-until/article_cdfd79ec-d215-5427-bec5-969b94eb651f.html

Lincoln Journal-Star. 2014 Sep 5. City's new well will prevent drought shortages, mayor says. http://journalstar.com/news/local/city-s-new-well-will-prevent-drought-shortages-mayorsays/article fafc1e2b-c81f-5013-9074-9a98a99d7a14.html

Lincoln Water System Facilities Master Plan. 2014. City of Lincoln, Nebraska. https://www.lincoln.ne.gov/city/pworks/water/facilities-master-plan.htm 
Lower Platte South Natural Resources District. 2014. Integrated Management Plan. http://www.lpsnrd.org/Programs/gwIntMgtPlan.pdf

Nebraska Association of Resources Districts. 2014. 2014 NRD Water Management Activities Summary. Lincoln NE.

Nebraska Supreme Court. 2010. Central Neb. Pub. Power v. North Platte Natural Resources District, 280 Neb. 533. https://casetext.com/case/central-neb-pub-power-v-north-platte-natural-reso

Omaha World-Herald. 2009 Sep 6. Lake's future still cloudy. Accessed Sept. 6, 2009: http://omaha.com/article/20090906/NEWS01/709069880

Omaha World-Herald. 2009 Sep 20. Strains build on Big Mac. Editorial.

Omaha World-Herald. 2012 May 8. Big Mac inflows could be 'new normal.' Omaha, Nebraska. Accessed May 8, 2012: http://www.omaha.com/article/20120508/NEWS01/705089952

Omaha World-Herald. 2012 Jul 25. Heat, drought are straining Midlands utilities. Accessed July 25, 2012: http://www.omaha.com/article/20120725/NEWS/707259920/1685

Omaha World-Herald. 2012 Sep 5. Lincoln residents helped save new trees. Accessed Sept. 5, 2012: http://www.omaha.com/article/20120905/NEWS09/120909888/1016

Sholes, M. 2012 Dec 5. Drought costs Nebraska corn crop nearly a quarter billion dollars. The Grand Island Independent. http://www.theindependent.com/news/ag news/drought-costs-nebraska-corn-crop-nearly-aquarter-billion-dollars/article 08bdb6c6-3f21-11e2-b870-001a4bcf887a.html

WOWT. 2015 Jul 21. Plans announced to conserve basin water. Omaha, Nebraska. Accessed Feb. 16, 2016: http://www.wowt.com/home/headlines/Plan-Announced-To-Conserve-Basin-Water--317806391.html 